\title{
The Ear Spool Site (41TT653): A mid-15th to early 17th Century A.D. Caddo site in the Sulphur River Basin, Titus County, Texas
}

Timothy K. Perttula

Heritage Research Center, Stephen F. Austin State University

Follow this and additional works at: https://scholarworks.sfasu.edu/ita

Part of the American Material Culture Commons, Archaeological Anthropology Commons, Environmental Studies Commons, Other American Studies Commons, Other Arts and Humanities Commons, Other History of Art, Architecture, and Archaeology Commons, and the United States History Commons

Tell us how this article helped you.

This Article is brought to you for free and open access by the Center for Regional Heritage Research at SFA ScholarWorks. It has been accepted for inclusion in Index of Texas Archaeology: Open Access Gray Literature from the Lone Star State by an authorized editor of SFA ScholarWorks. For more information, please contact cdsscholarworks@sfasu.edu. 
The Ear Spool Site (41TT653): A mid-15th to early 17th Century A.D. Caddo site in the Sulphur River Basin, Titus County, Texas

\section{Creative Commons License}

\section{(c) (1) \&}

This work is licensed under a Creative Commons Attribution-NonCommercial 4.0 International License 
THE EAR SPOOl SITE (41TT653): A MID-15 ${ }^{\mathrm{TH}}$ TO EARLY $17^{\mathrm{TH}}$ CENTURY A.D. CAddo Site in the Sulphur River Basin, Titus County, TeXas

\section{Timothy K. Perttula}

\section{Introduction}

The Ear Spool site (41TT653) is a rather unique ancestral Caddo settlement in the East Texas Pineywoods. More specifically, it is situated along a small tributary to East Piney Creek, itself a northwardflowing tributary to White Oak Creek in the Sulphur River basin (Figure 1).

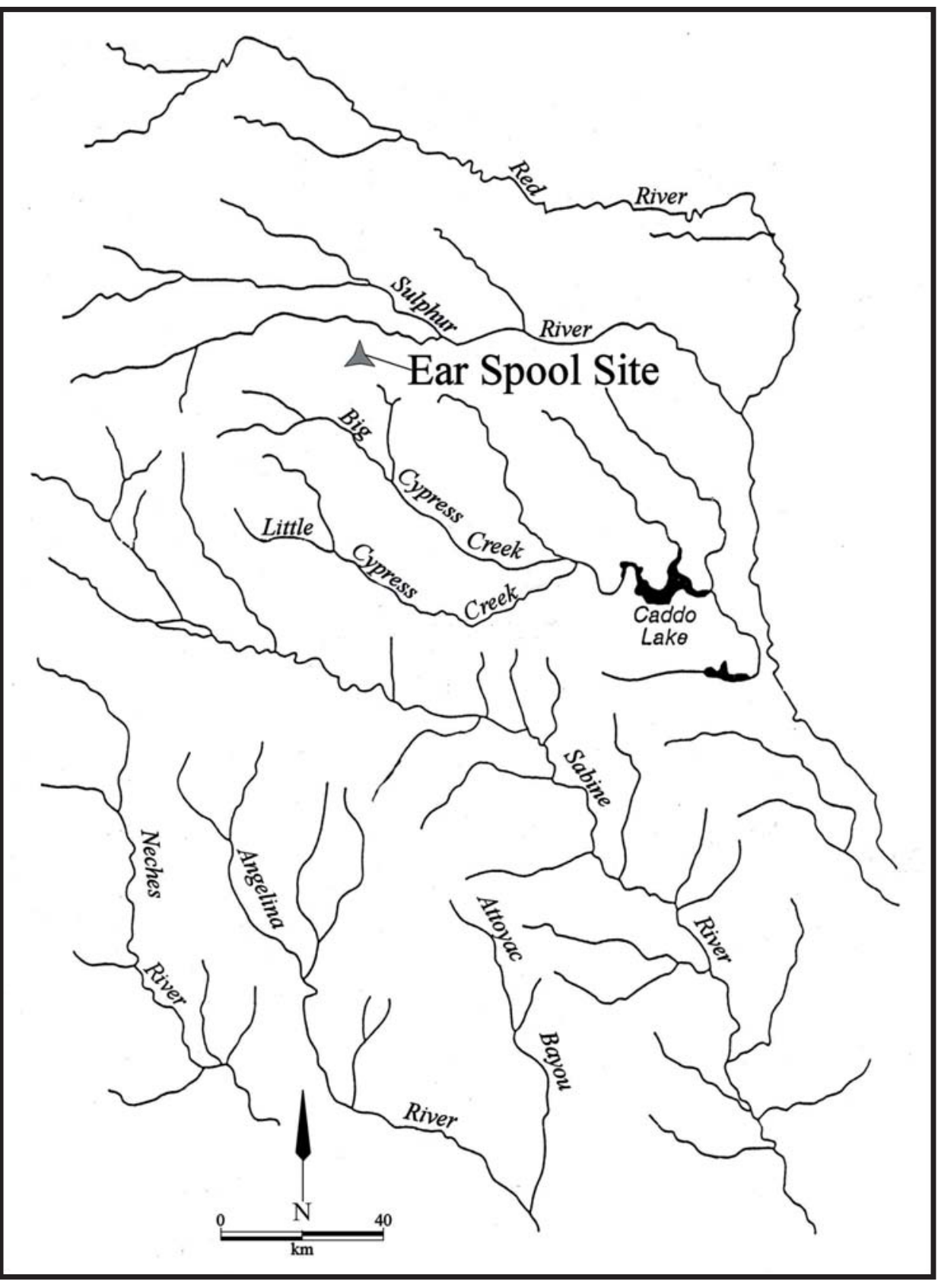

Figure 1. Location of the Ear Spool Site in East Texas. 
What makes the site unique is its diverse architectural character as seen in the archeological evidence of four buildings in two different Late Caddo period, Titus phase occupations, separated by as much as 2-3 generations, from the mid- $15^{\text {th }}$ century to the early $17^{\text {th }}$ century A.D. In particular, it is the construction of two specialized structures in the earlier Caddo occupation in shallow pits that is most notable, along with evidence of marker posts in two different intra-site contexts. Both of these structures had prepared clay floors, one also had a southwest-facing extended entranceway, and then both of these structures were deliberately destroyed by burning and burial with sediments. The later structures were larger circular residential structures, one of which was deliberately burned down, but not covered with any sediments. Galan (1998) and Perttula and Sherman (2009) has discussed the archeological investigations of the Ear Spool site in detail, characterizing the site's archeological features and findings. However, these publications are very limited in distribution, basically being limited to Cultural Resource Management archeologists working in Texas, but I believe that the findings from the Ear Spool site warrant broader consideration because of its distinctive and dual sacred and secular nature.

\section{Excavations}

Extensive excavations, both hand and machine-based, were completed at the Ear Spool site. The site covers a ca. 80 x $45 \mathrm{~m}$ area of a sandy ridge, then in an improved pasture. The excavations uncovered evidence for four Caddo structures, an open area or courtyard between the structures, and a series of ancillary features (Figures 2 and 3).

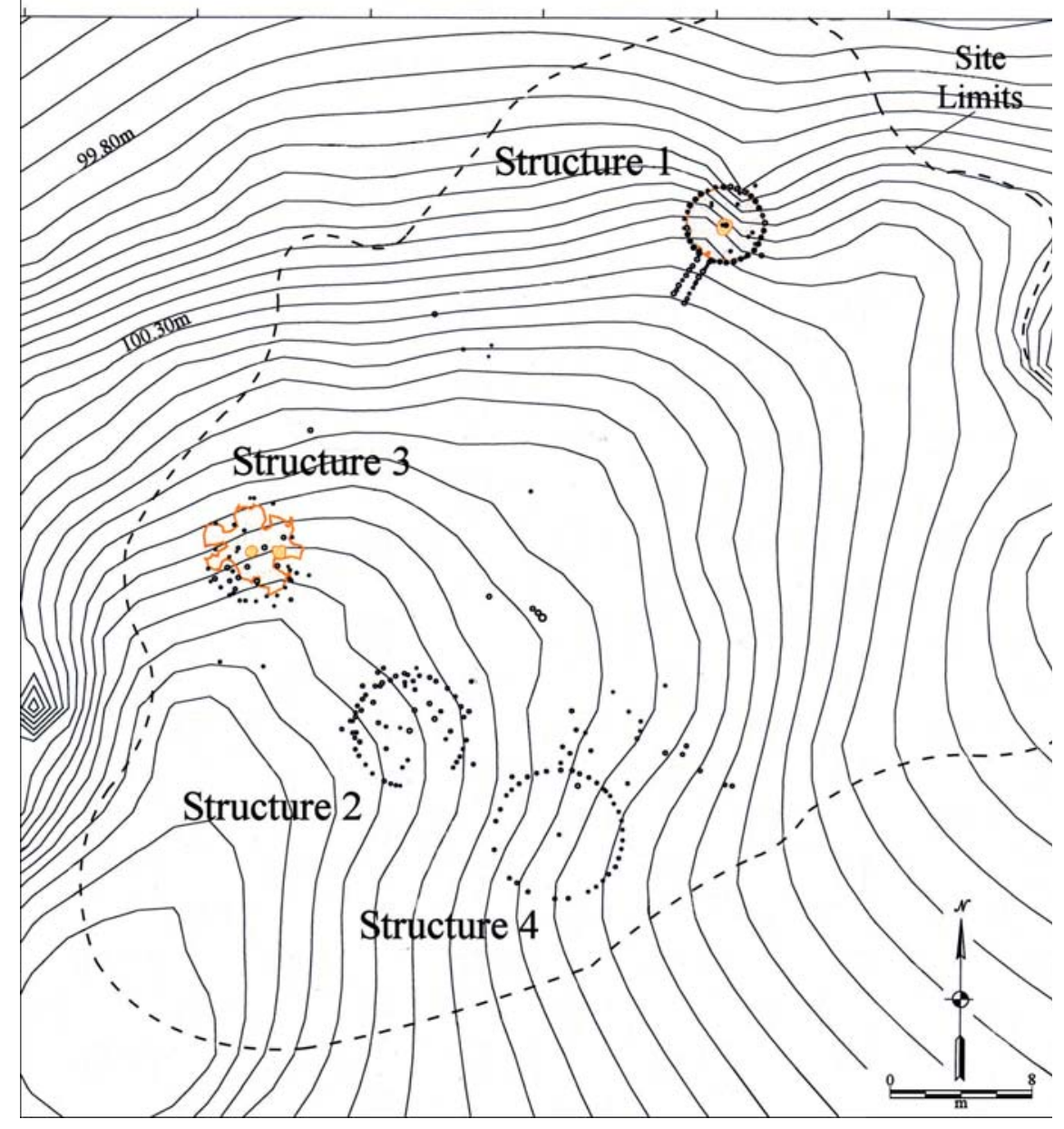

Figure 2. Site topography, locations of structures and other post holes. 


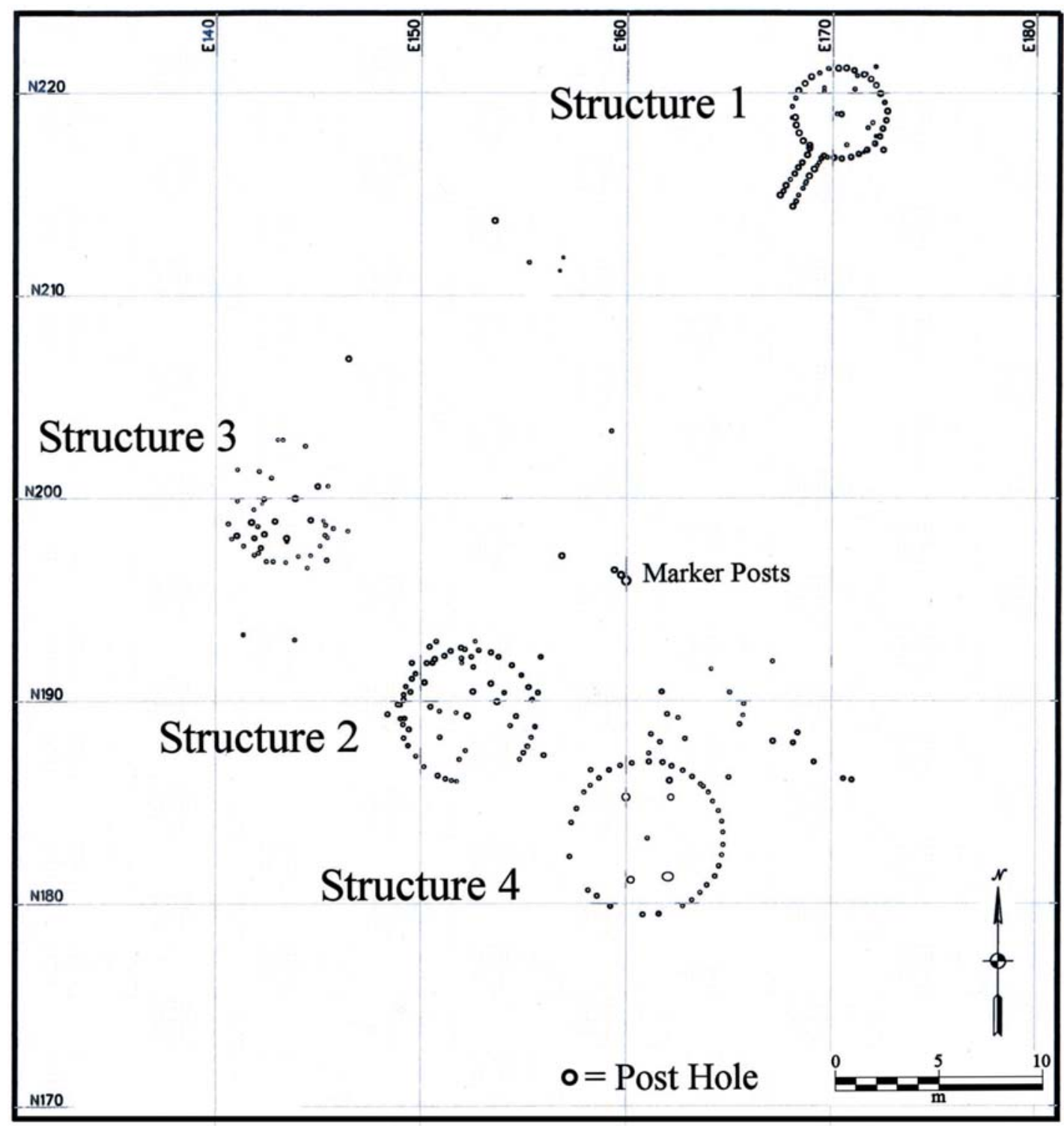

Figure 3. Structures 1-4, marker posts, and other post holes.

Following the excavation of $7750 \times 50 \mathrm{~cm}$ units across the site to obtain information on the distribution of different categories of artifacts (Figure 4), a number of backhoe trenches were excavated in areas where buried archeological deposits and/or artifact concentrations (especially daub and bone) had been identified to search for concentrations of cultural features. Several of the trenches encountered buried features that turned out to be associated with Structures 1,2, and 3. Artifacts were generally concentrated in these three structures, and in outdoor work areas between Structure 1 and Structures 2 and 3.

Block excavations $\left(117 \mathrm{~m}^{2}\right)$ were then placed over Structures 1, 2, and 3 to expose and define their archeological and architectural content, and another $24 \mathrm{~m}^{2}$ were excavated in outdoor work areas between the structures. The final work effort consisted of large-scale bulldozer stripping areas between the block excavations. At that time, Structure 4 and a burial (Burial 3) were exposed, along with additional pits, post holes, and a small midden deposit. 


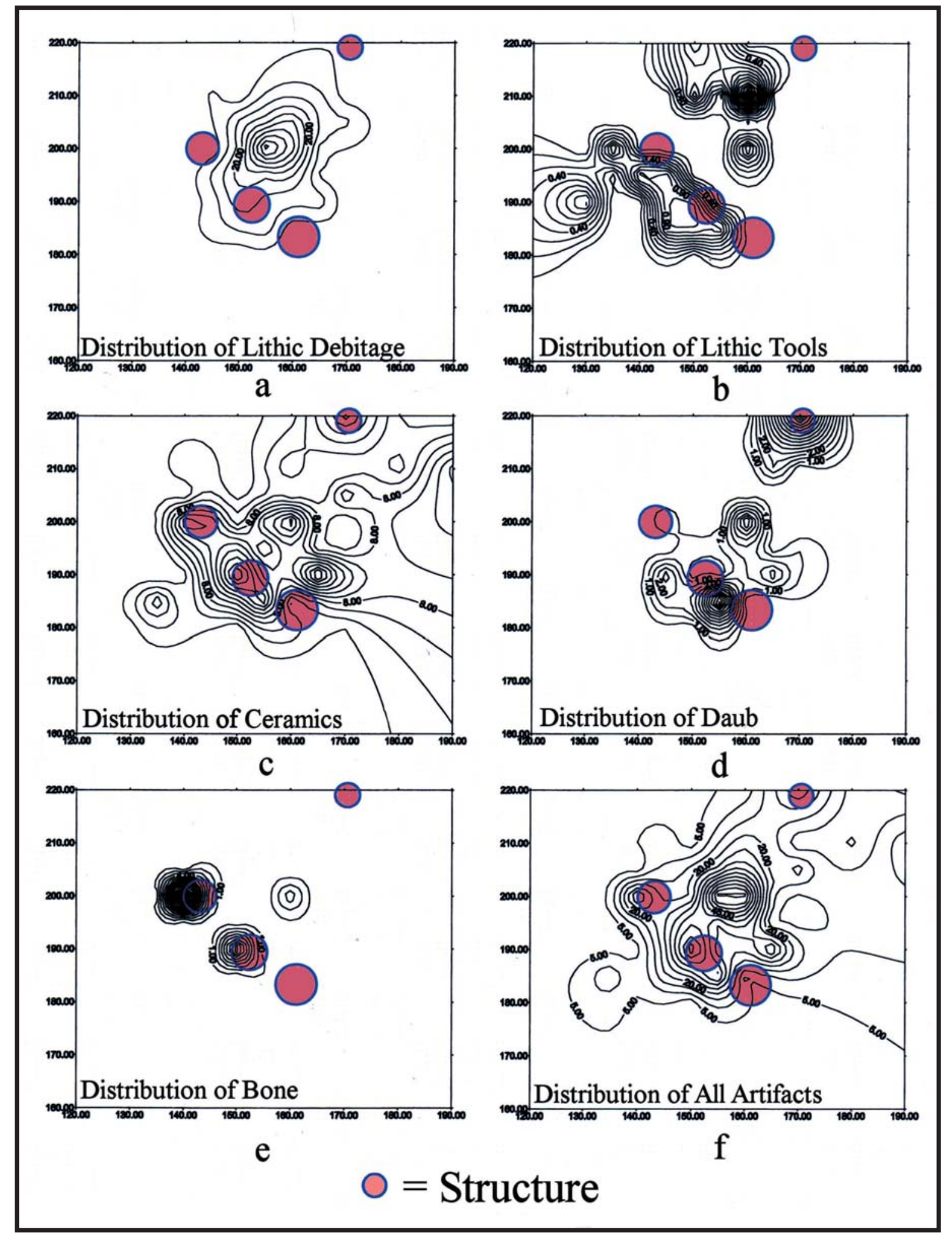

Figure 4. Intra-site distribution of recovered artifacts superimposed over the locations of Structures 1-4: a, lithic debris; b, lithic tools; c, ceramic sherds; d, daub; e, animal bone; f, all artifacts. 
The two components at the Ear Spool were defined primarily on the basis of radiocarbon dates from structures and features (see below) as well as similarities and differences in the kinds and proportions of decorated rim and body sherds from fine ware and utility ware vessels. This is based on 606 decorated rim and body sherds from Component I and 1025 decorated rim and body sherds from Component II. Principal ceramic types in Component I, which is estimated to date from the mid-15 $5^{\text {th }}$ century A.D. to the early $16^{\text {th }}$ century, include Ripley Engraved, Wilder Engraved, Maydelle Incised, Bullard Brushed, Pease Brushed-Incised, Harleton Appliqued, and La Rue Neck Banded. The Component II principal types include Ripley Engraved, Wilder Engraved, Taylor Engraved, Simms Engraved, Avery Engraved, Mockingbird Punctated, Maydelle Incised, Bullard Brushed, Karnack Brushed-Incised, La Rue Neck Banded, and McKinney Plain, and this component is estimated to date from the late $16^{\text {th }}$ century to the early $17^{\text {th }}$ century. The stylistic differences between the two components are listed in Table 1.

Table 1. Summary of ceramic stylistic differences between Components I and II.

Component I

moderate number of brushed sherds (31\%)

brushed-appliqued decorations

predominance of cross-hatched incised

punctated-incised sherds with diagonal incised elements

neck-banded-appliqued-diagonal incised decorative

element

punctated-incised-appliqued rim and body decorations

scroll, scroll and semi-circle, and circle Ripley

Engraved motifs

2 times higher proportions of slipped sherds (mainly

interior-exterior surfaces)

engraved sherds with red and white pigments

shell-tempered sherds (1.5\%) in Structure 1

smaller vessels (mean orifice diameter of $19.8 \pm 6.2 \mathrm{~cm}$
Component II

\author{
higher amounts of brushed sherds (52\%) \\ more overlapping brushed sherds \\ equal portions of cross-hatched and diagonal \\ incised rims \\ opposed or hachured incised rims \\ tool and fingernail punctated decorations on \\ vessel body \\ punctated-incised-brushed sherds \\ pendant triangle Ripley Engraved motif
}

few slipped sherds, mainly exterior slipping

only

no engraved sherds with pigments

presence of Taylor Engraved and Simms

Engraved

larger vessels (mean orifice diameter of

$24.1 \pm 5.9 \mathrm{~cm}$

More than 300 cultural features were identified in the Ear Spool site excavations. Component I includes two clay floor-lined structures (Structures 1 and 3) and pits and post holes in an outdoor work area (Area 3) (Figure 5). The two structures were about $20 \mathrm{~m}$ apart, with an open area between them. Three of the posts in Area 3 are marker posts, about $17 \mathrm{~m}$ east of Structure 3, and these were not intended for use in structures but to mark certain special areas or features in an open courtyard at the Ear Spool site community. These marker posts are larger (24-41 cm in diameter) than typical wall posts, which average $17-18 \mathrm{~cm}$ in diameter. 


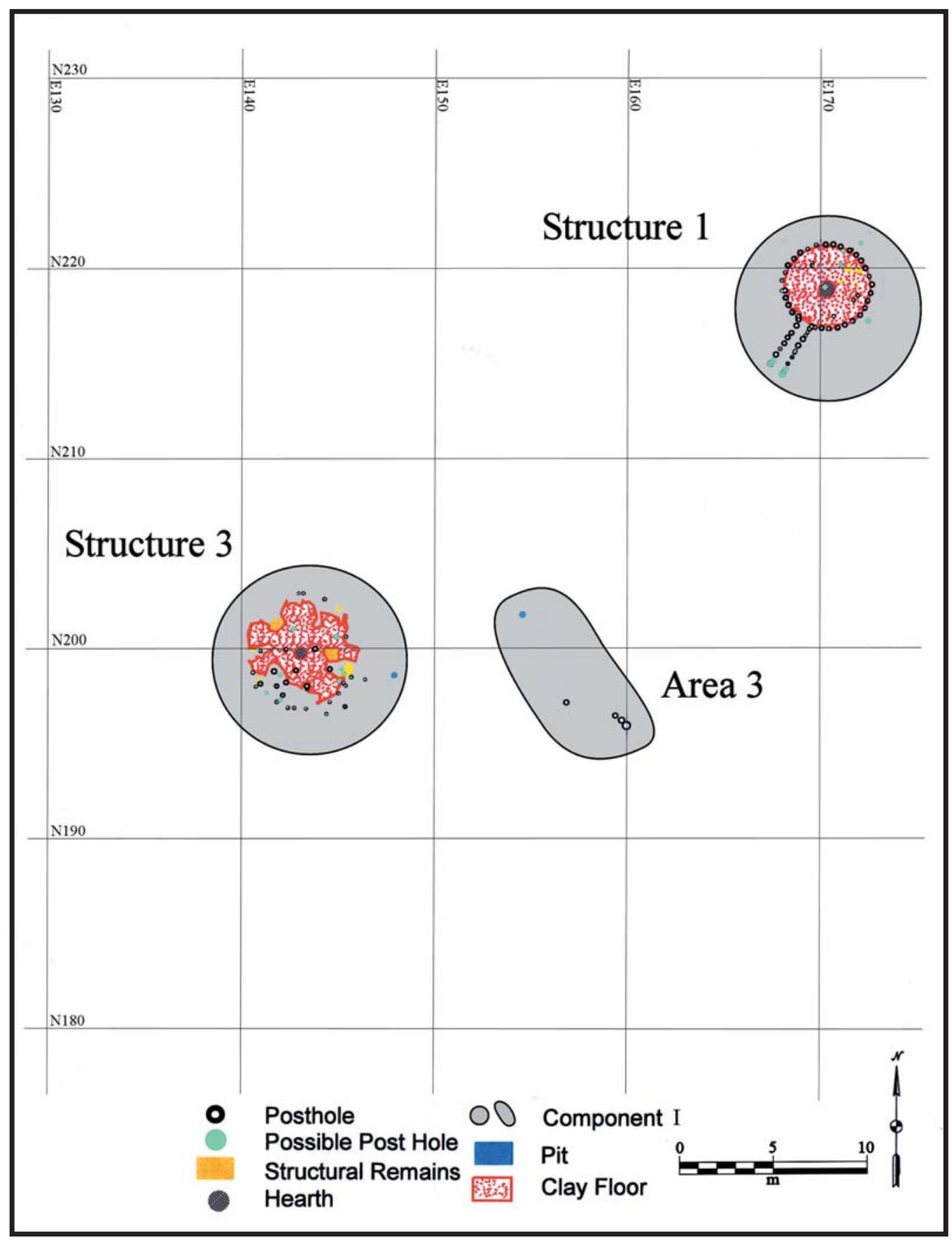

Figure 5. Component I features and areas.

Marker posts are common in open courtyards in certain Mississippian sites (see Pauketat and Alt 2005), but have not been previously documented in Titus phase contexts. Such poles may have been painted, hung with scalps and feathers, and probably embodied "supernatural forces, legends, social memories, and identities" (Pauketat and Alt 2005:228). Carter (1995:90-93, 96-99) has discussed Historic Caddo rituals concerning the use of singular tall poles. According to a Spanish priest writing in 1691, the Nabedache Caddo (who lived along the Neches River in East Texas) erected a pole in their village, and:

on it hangs a portion of everything they are offering to God. In front of the pole a fire is burning. Near by is a person who looks like a demon. He is the person who offers the incense to God, throwing tobacco and buffalo fat into the fire. The men collect themselves around the blaze; each 
one takes a handful of smoke and rubs his whole body with it. Each believes that, because of this ceremony, God will grant whatever he may ask-whether it be the death of his enemy or swiftness to run. On other occasions, the incense is not offered by burning in this way. In this case a kind of burned pole is taken and set up by the fire. This pole, and the fat for the incense-which has already been burned-they offer to God.

The later Component II covers a ca. 35 × $35 \mathrm{~m}$ area of the landform, and had two structures (Structures 2 and 4), several burials, and a number of outdoor work areas with pits (including a large outdoor storage pit north of Structure 4 and several smudge pits) and post holes, including a midden deposit in Area I (Figure 6). The distribution of post holes in outdoor work areas may represent the locations of drying racks, arbors, and ramadas (Figure 7).

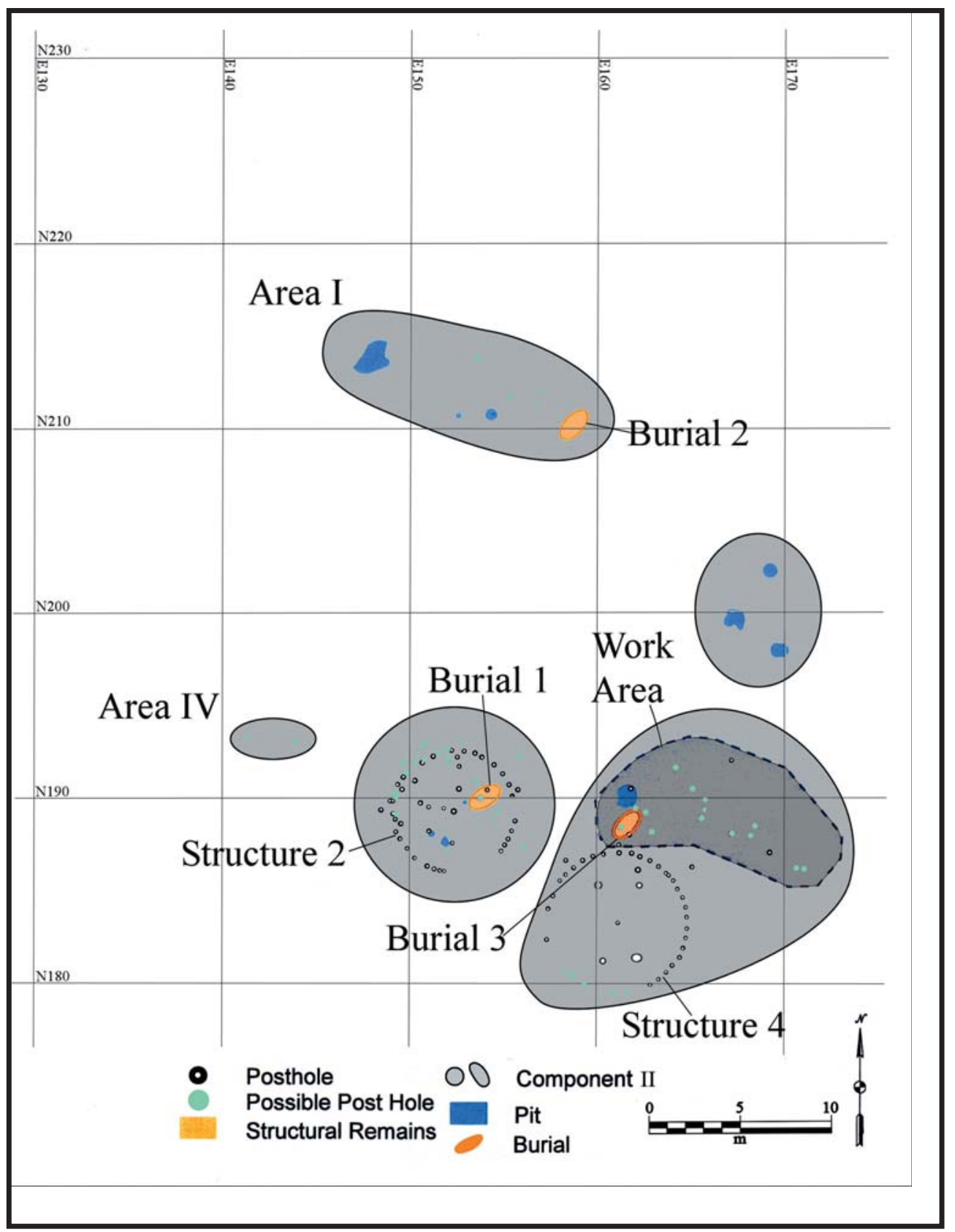

Figure 6. Component II features and areas. 


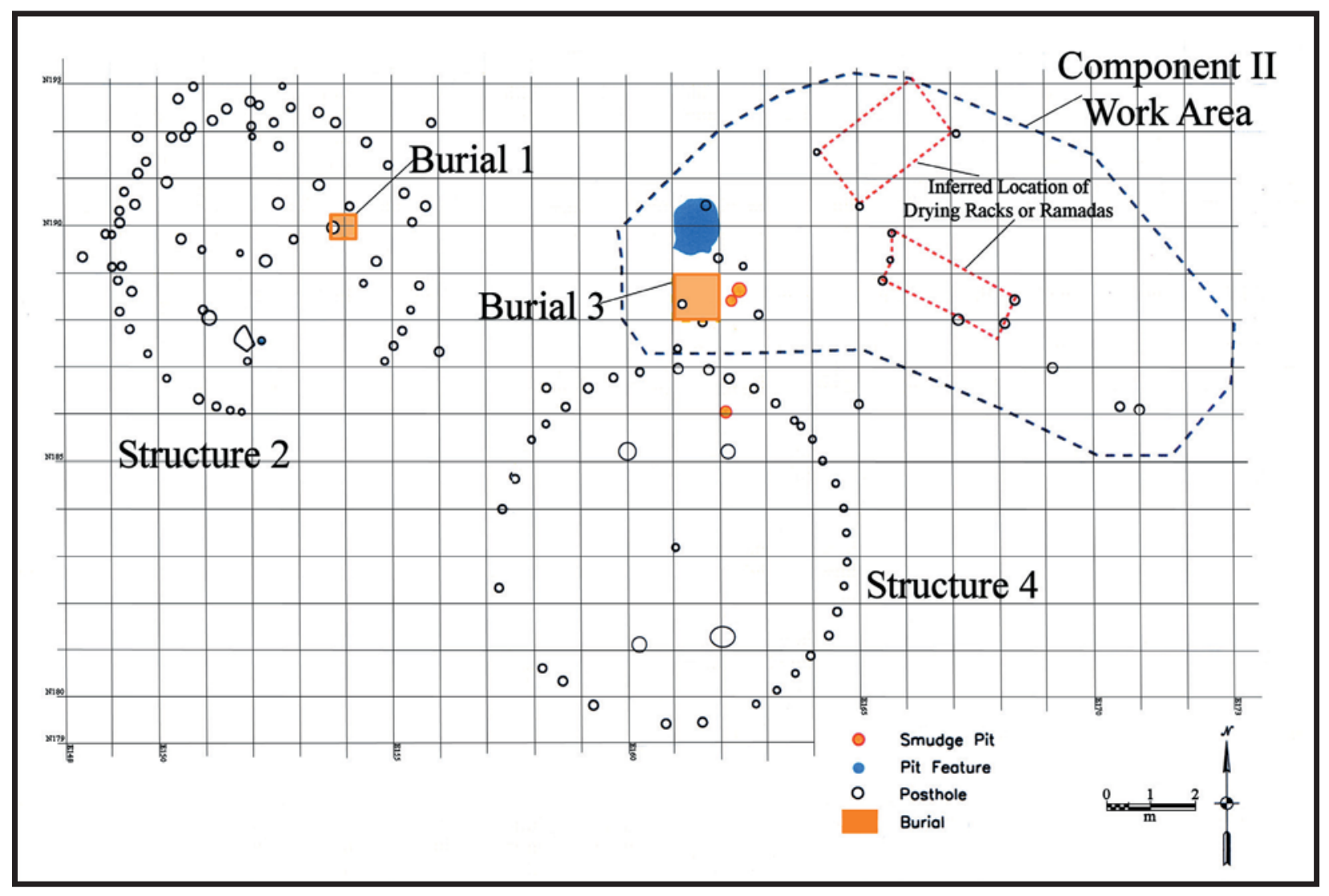

Figure 7. Component II structures and work area.

Structure 1 was built in a shallow circular pit and had a well preserved reddish-brown clay floor, with sand floors just underneath and above it, and a central hearth. It also had an extended entranceway that faced to the southwest, in the direction of Structure 3 (Figure 8a-b). It is approximately $4.5 \mathrm{~m}$ in diameter, with an estimated $16.27 \mathrm{~m}^{2}$ of floor space. The extended entranceway, marked by a series of posts and evidence of an entranceway trench, is $2.5 \mathrm{~m}$ in length and oriented to the southwest.

Structure 1 is not a residential structure, but is suspected to have been used primarily for the conduct of rituals and ceremonies on special occasions. This is suggested because of its unique architectural (i.e., extended entranceway and the building of the structure in a pit), construction/destruction details (i.e., prepared clay floor, intentional structure destruction, and capping with sediments), and commemorative (i.e., placement of a marker post [Feature 49] through the central hearth, Figure 8c) elements.

Structure 1 was deliberately burned down, generating considerable quantities of daub and other burned structural debris across much of the structure floor (see Figure 8a). The high frequencies of daub from all three structures (Table 2), more than several thousand pieces, indicate that all of them were burned, but the very substantial amounts of daub in Structures 1 and 2 suggest these two had the thickest covering of daub on structure walls. 


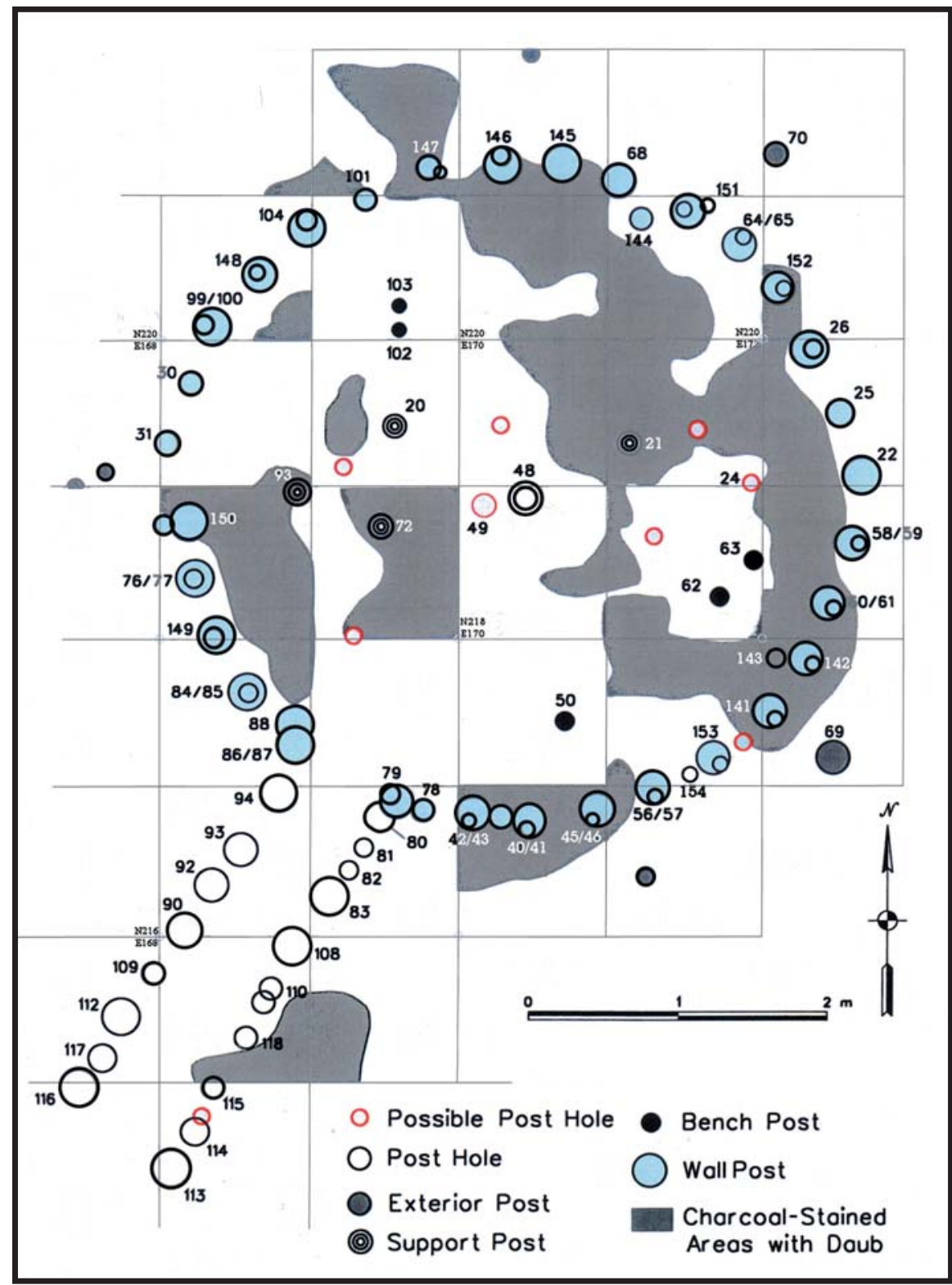

Figure 8a. Structure 1: Plan map of Structure 1 and charcoal-stained areas with daub.

Table 2. Densities of daub pieces in Structures 1-3.

Structures

Mean Density per $\mathrm{m}^{3}$

Range by level in Density per $\mathrm{m}^{3}$

Structure 1

90.5

$6.7-145.4$

Structure 2

46.3

$6.7-89.8$

Structure 3

13.5

$1.0-61.0$ 


\section{Extent of Clay Floor}

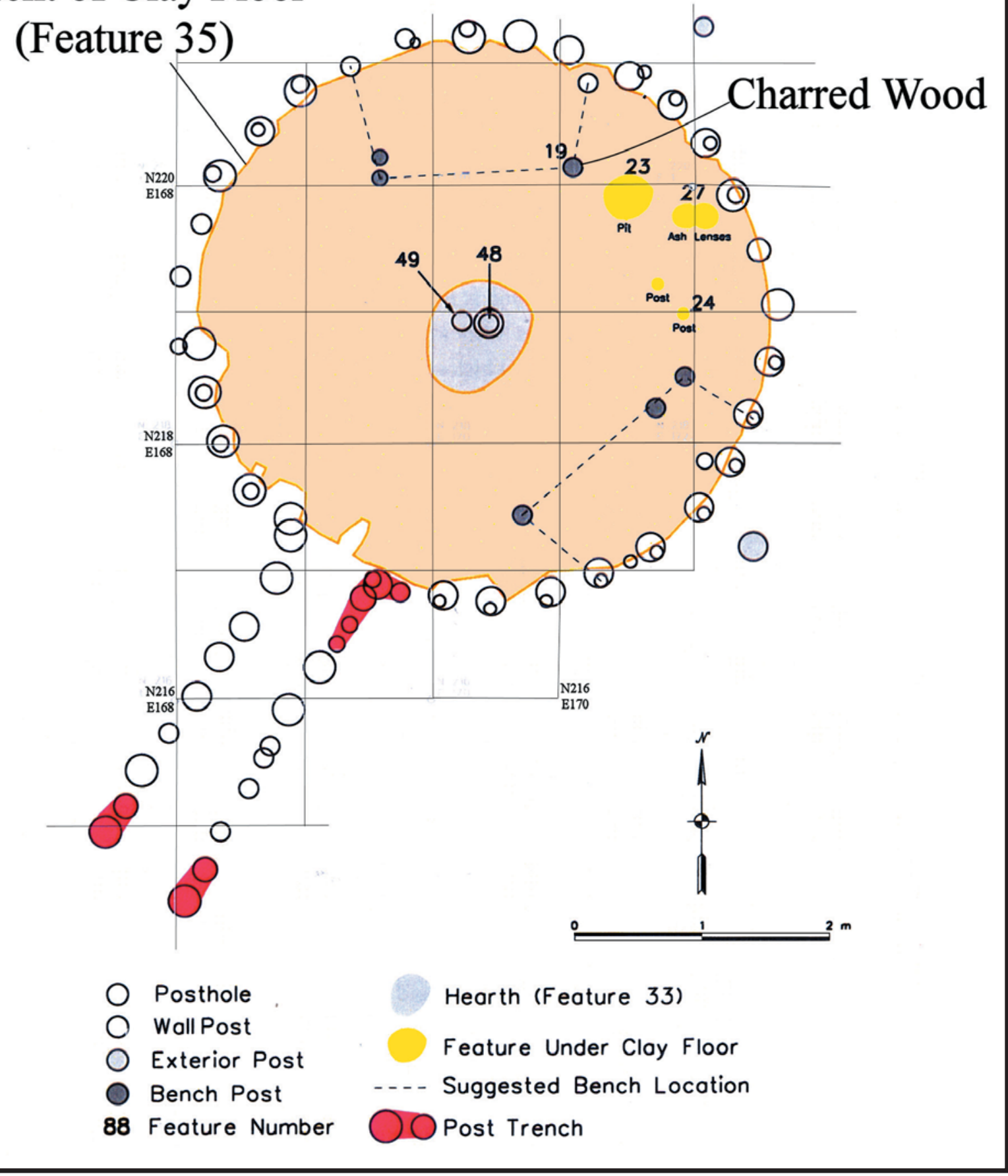

Figure 8b. Clay floor and other internal details; c, upper and lower posts inside Structure 1. 
Structure 1 was covered with relatively clean sediments shortly after it was consumed by fire, and these sediments were probably dumped on the burning structural materials at a certain point, thus smothering the fire, and creating much of the blackened daub and burned clay. The covering sediments created a small mound over Structure 1. The $17 \mathrm{~cm}$ in diameter marker post (Feature 49) in Structure 1 is situated above the center of the central hearth and central post, and intruded into the central hearth (Feature 33, see Figure 8c) from the small mound deposits, suggesting it was placed shortly after the structure was abandoned and burned; the fill of Feature 49 consists primarily of burned daub. A similar marker post excavated through a mound deposit and the hearth of a buried and burned house has been documented at the Pilgrim's Pride site in Titus phase times (Perttula 2005:312 and Figure 8-9). In this case, however, the marker pole was almost $80 \mathrm{~cm}$ in diameter and extended well below the hearth, reaching the original ground surface at $170 \mathrm{~cm}$ bs.

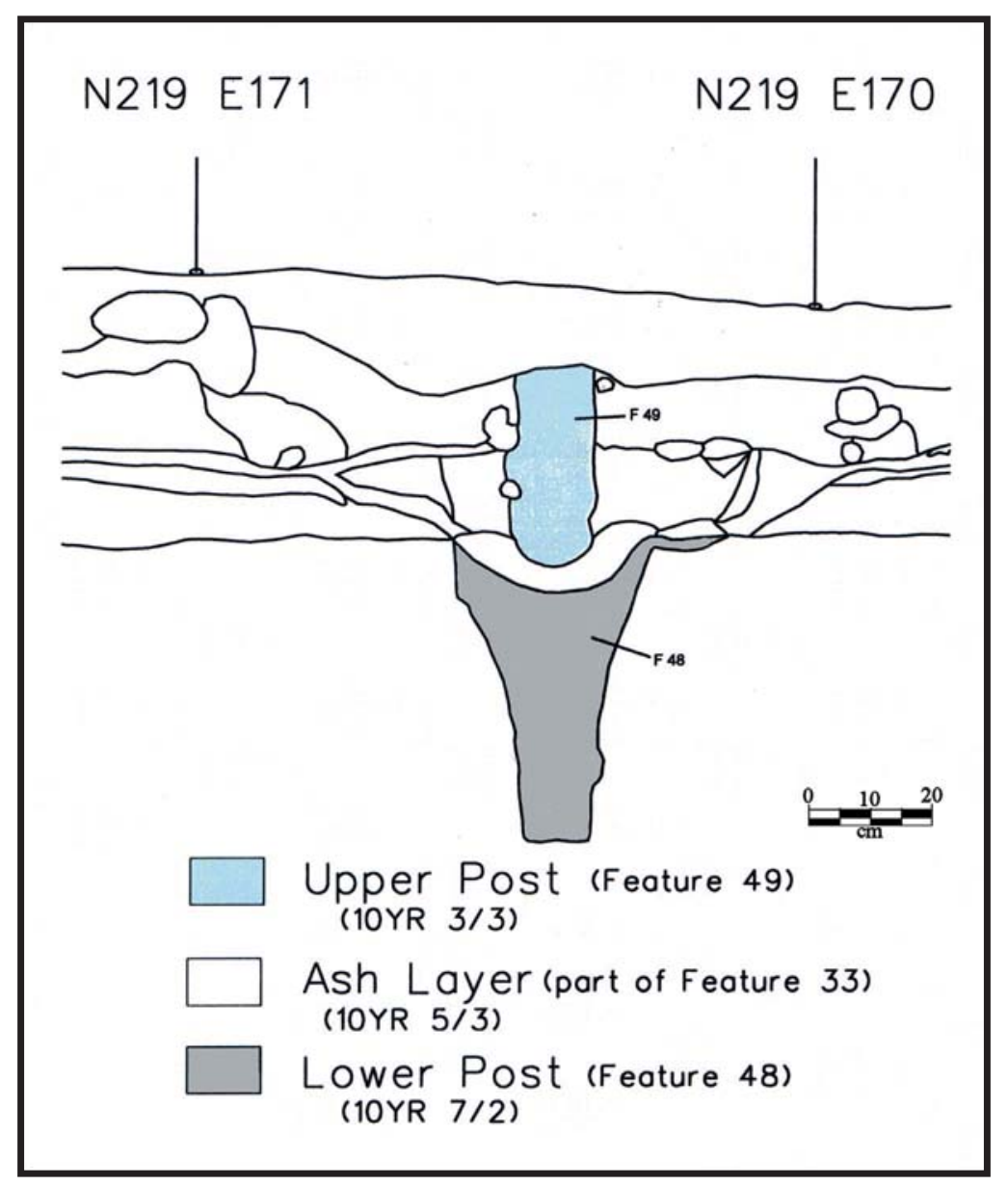

Figure 8c. Upper and lower posts inside Structure 1.

Structure 2 is a circular building approximately $6.75 \mathrm{~m}$ in diameter, marked by an arc of wood posts, support posts, and a center post (Figure 9a-b). Its estimated floor space is $33.83 \mathrm{~m}^{2}$, and it is considered a residential structure for a family of Caddo people. The quantity of daub in the Structure 2 archeological deposits (see Figure 4d) indicate that it was a wattle and daub-covered structure that was burned down upon its abandonment. Burial 1, that of a child (see below), is under the floor in the northeastern part of the structure. The placement of the burial of children inside of residential structures is a well-documented Caddo mortuary practice in ancestral times, and it is likely that Burial 1 was part of a deliberate action by the Caddo residents at Ear Spool to create a social memory within the community, as a way to anchor this feature to an evolving social landscape (e.g., Chesson 2001). 


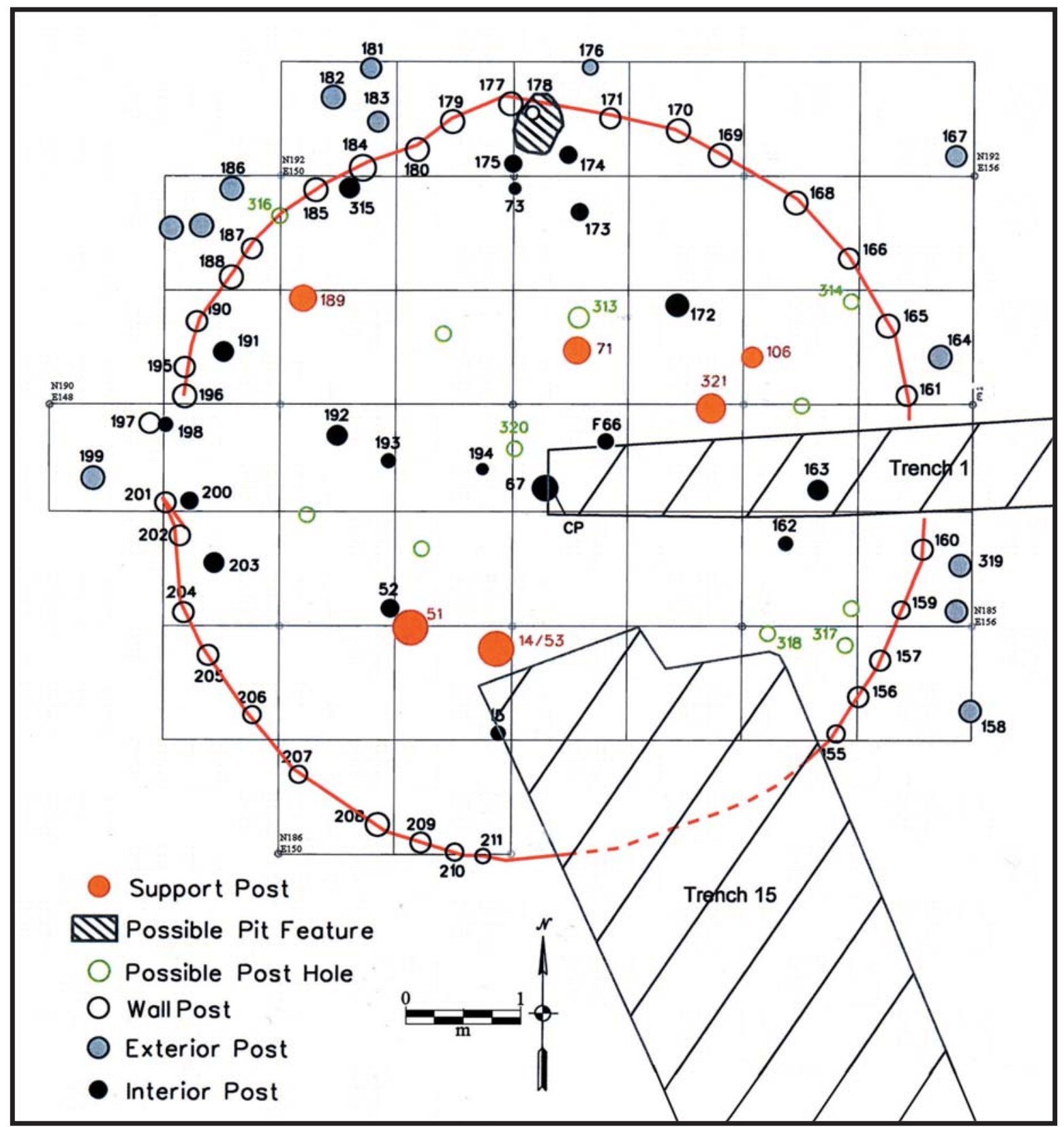

Figure 9a. Structure 2: plan map of post holes and features. 


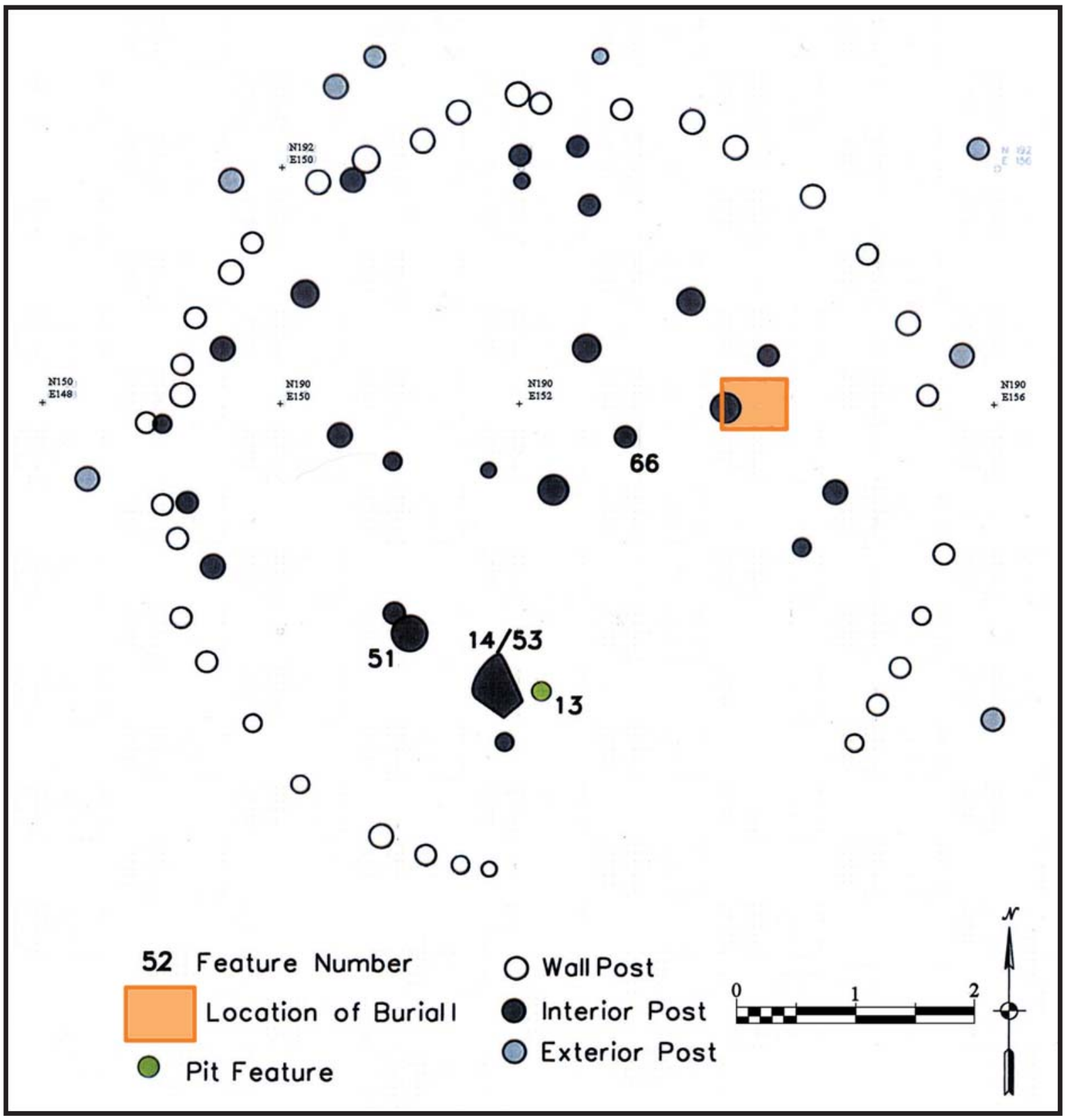

Figure 9b. Sturcture 2: Wall posts and interior and exterior posts. 
Structure 3 is a second special purpose structure in Component I. The circular structure was built in a shallow pit about $5.5 \mathrm{~m}$ in diameter, had a clay-lined floor, interior support posts, and a central hearth (Figure 10a-b); there was no clear entrance. There was a sand floor underneath the clay-lined floor. The structure was burned down, and there were substantial charcoal-stained structural debris and daub above the claylined floor and throughout the pit. The structure pit was also used as a dumping area for trash following its abandonment, based on the densities of animal bone in its fill (see Figure 4e), probably over a protracted basis in the Component I and II occupations, and sediments were also used to fill the pit. No sediments were piled up over the burned structural remains and pit, unlike Structure 1.

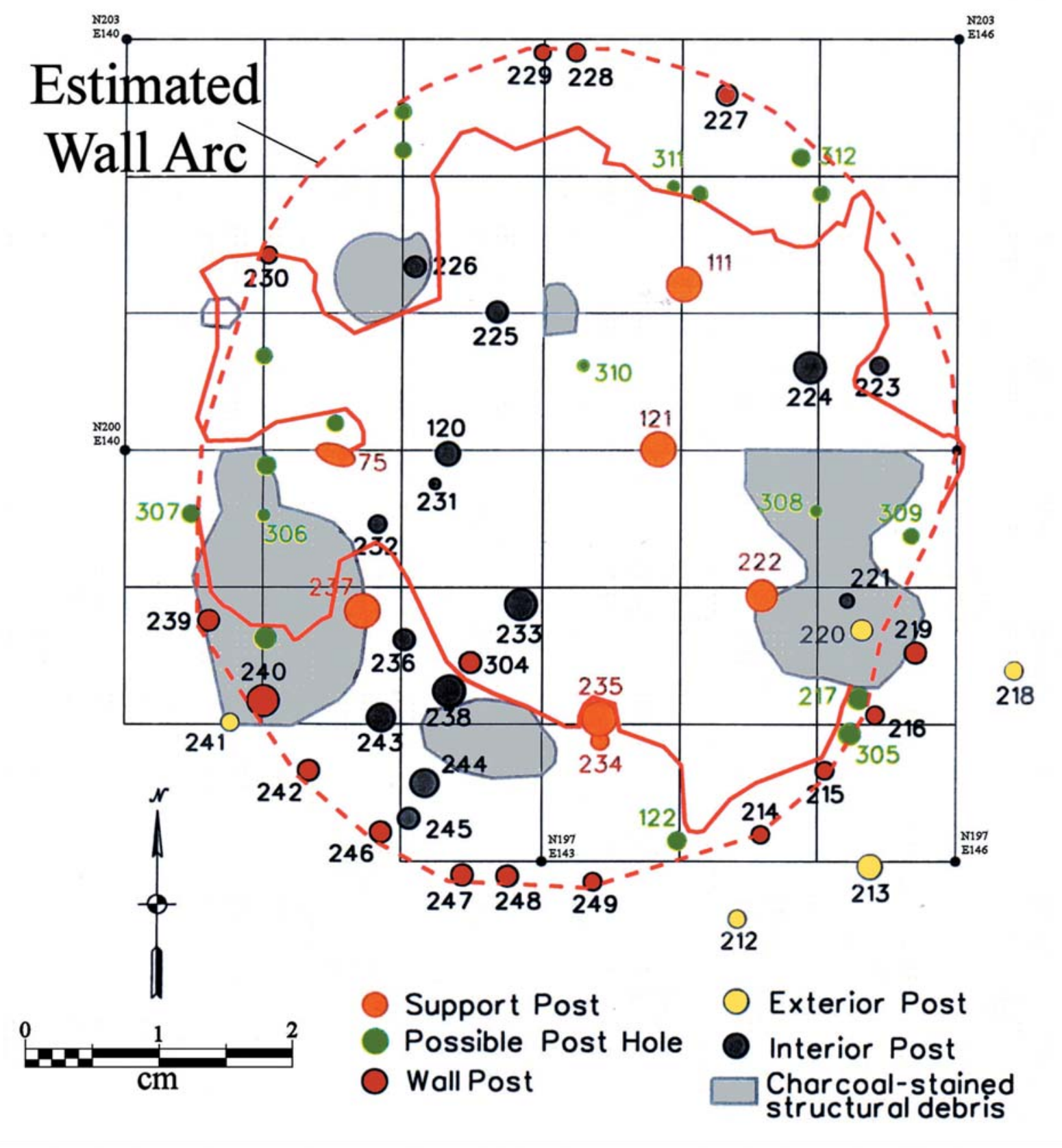

Figure 10a. Structure 3: extent of clay floor, structural debris, and post holes. 


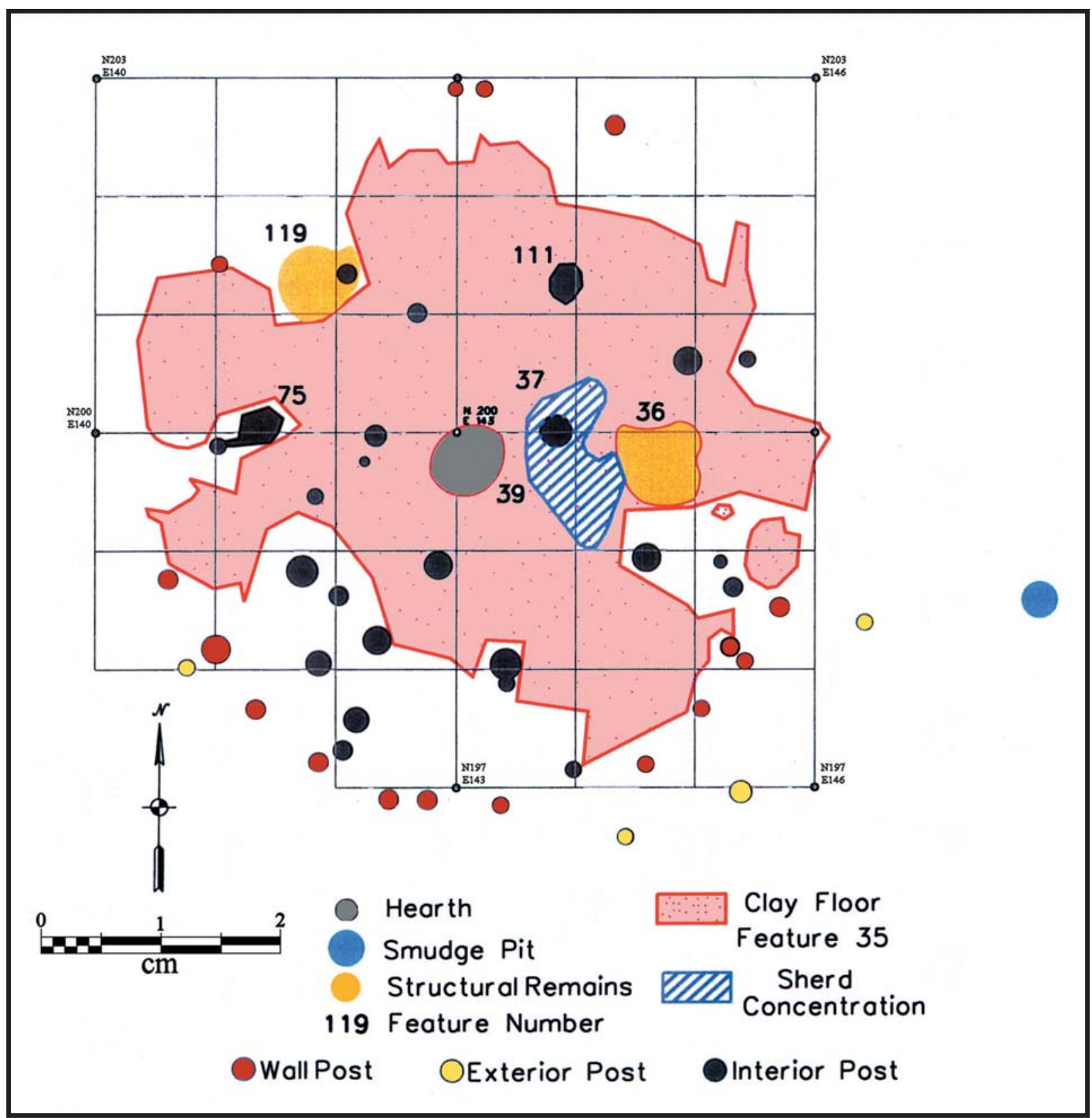

Figure 10b. Structure 3: clay floor and other features.

Structure 4, in Component II, is a large (7.5 $\mathrm{m}$ in diameter) circular structure with four support posts and a central post (Figure 11). Its estimated floor space is $44.4 \mathrm{~m}^{2}$, large enough to house an extended family of Caddo people. Spacing of the wall posts suggest the entrance to Structure 4 was on its western side, facing Structure. 


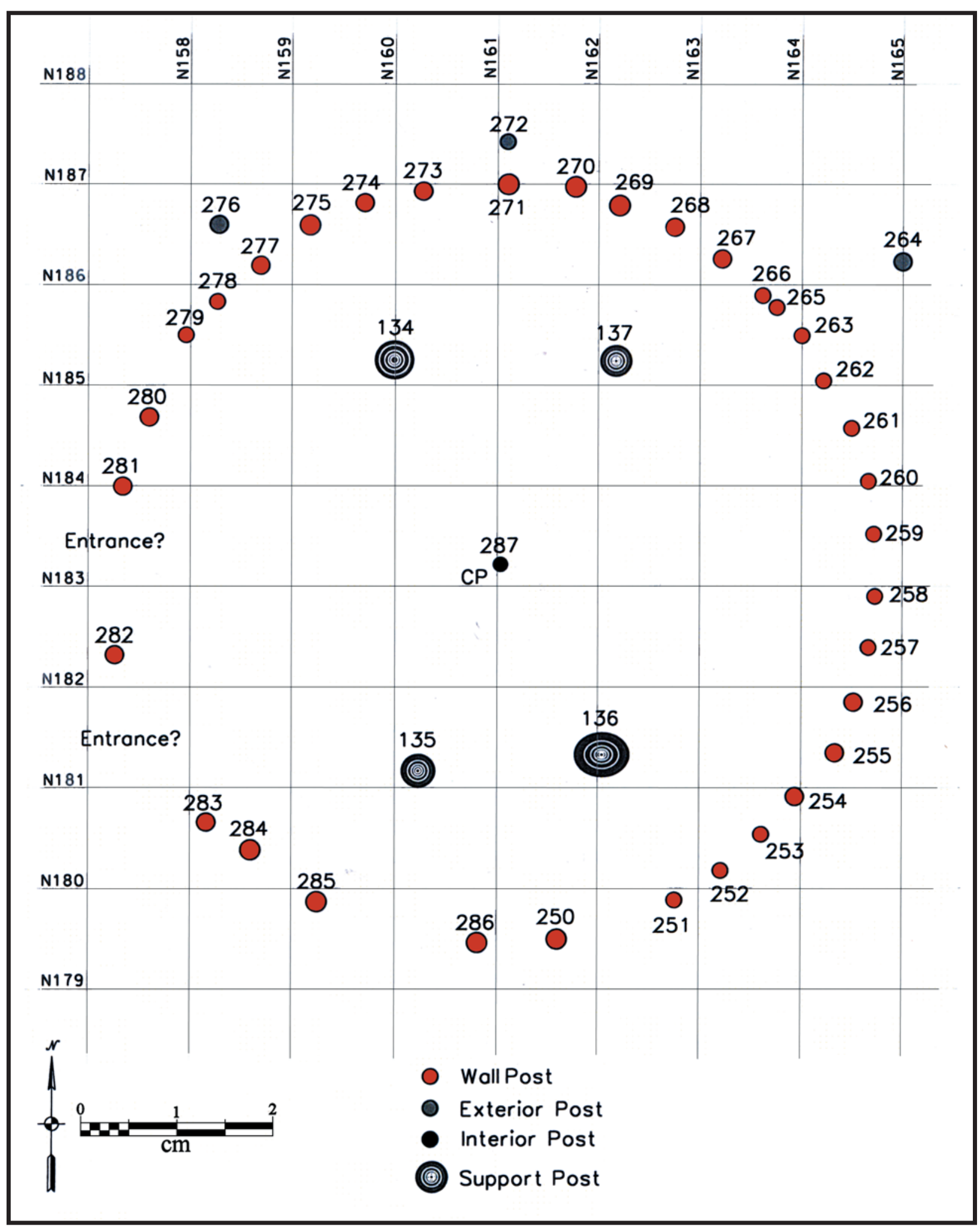

Figure 11. Structure 4 post hole pattern. 
Structure 4 was not associated with an especially high artifact density, as were Structures 1-3 (see Figure 4), and it was not identified during the initial phases of the data recovery work at Ear Spool, but was only identified during the final machine-stripping of the archeological deposits. It is possible that Structure 4 was occupied for a shorter duration than the site's other structures, or was used differently than the other structures, such that cultural materials were more often discarded outside it rather than inside. Structure 4 was also not burned down upon its abandonment, unlike Structures 1-3.

\section{Radiocarbon Dates}

A number of radiocarbon dates have been obtained from the four structures at the site as well as from several outdoor work area features. Using 0xCal v4.1.7, the summed probability distributions of the calibrated dates indicate two peaks in the distribution that correspond to the two different components: A.D. 1450-1520 (Component I) and A.D. 1590-1620 (Component II ) (Figure 12).

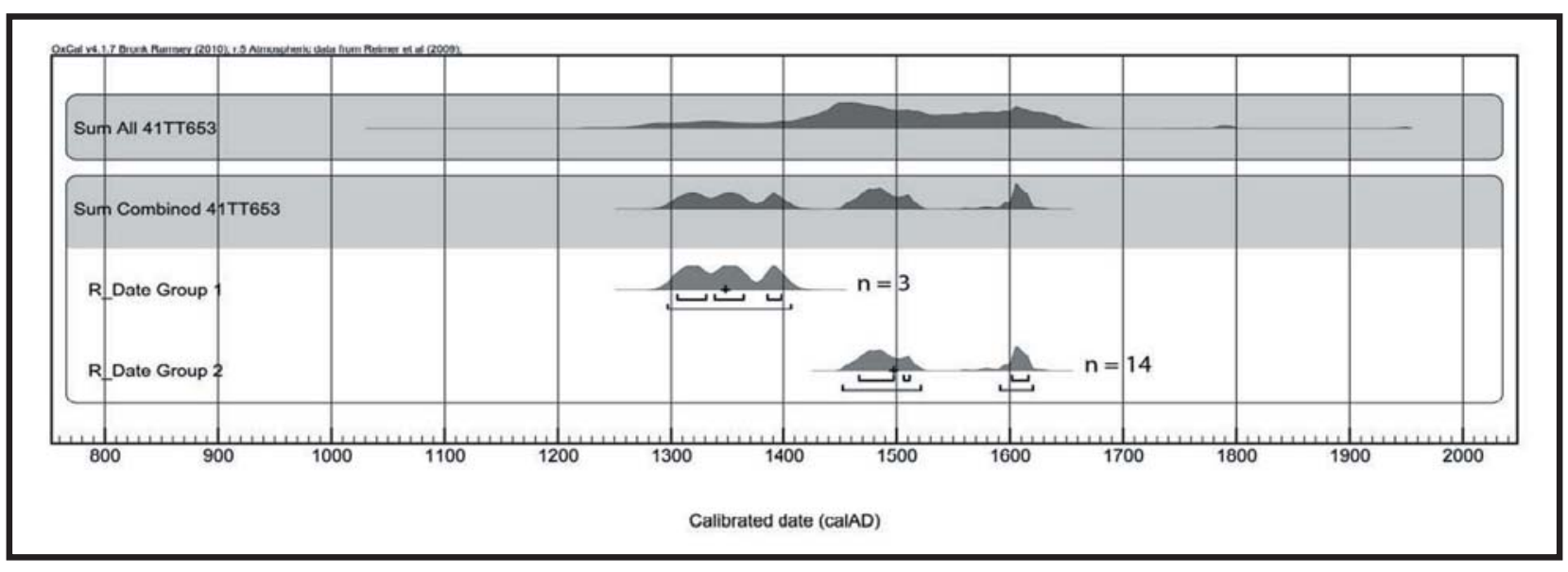

Figure 12. Summed probability distribution of radiocarbon dates from the Ear Spool site.

Several Oxidizable Carbon Ratio (OCR) dates ( $\mathrm{n}=5$ ) have also been obtained from features and structures (Perttula and Sherman 2009:172-173). Those that correspond well to the summed probability distribution age ranges are A.D. $1593 \pm 10$ from Feature 1 in the Component II work area and A.D. $1620 \pm 9$ from Feature 34 in Structure 3 (Component II). The other three OCR dates are too young given the results of the radiocarbon dating and the range of associated decorated ceramics from structures and features.

\section{Burials and Funerary Offerings}

The three Caddo burials found at the Ear Spool site are part of the Component II Caddo occupation (see Figure 6). Burial 1 is inside Structure 2, Burial 3 is just outside Structure 4, and Burial 2 is about $20 \mathrm{~m}$ to the north in Area I. Funerary offerings with the burials include 12 ceramic vessels.

Burial 1 is that of a child, likely less than 1 month of age, placed in a $50 \times 40 \mathrm{~cm}$ pit (Perttula and Sherman 2009:Figure 6-19) that is oriented roughly north-south, with the head of the child at the north end of the grave. A single ceramic vessel was placed in the grave as a funerary offering. This vessel is a medium-sized shell and grog-tempered compound bowl of the Avery Engraved type (Figure 13 and Table 3). 


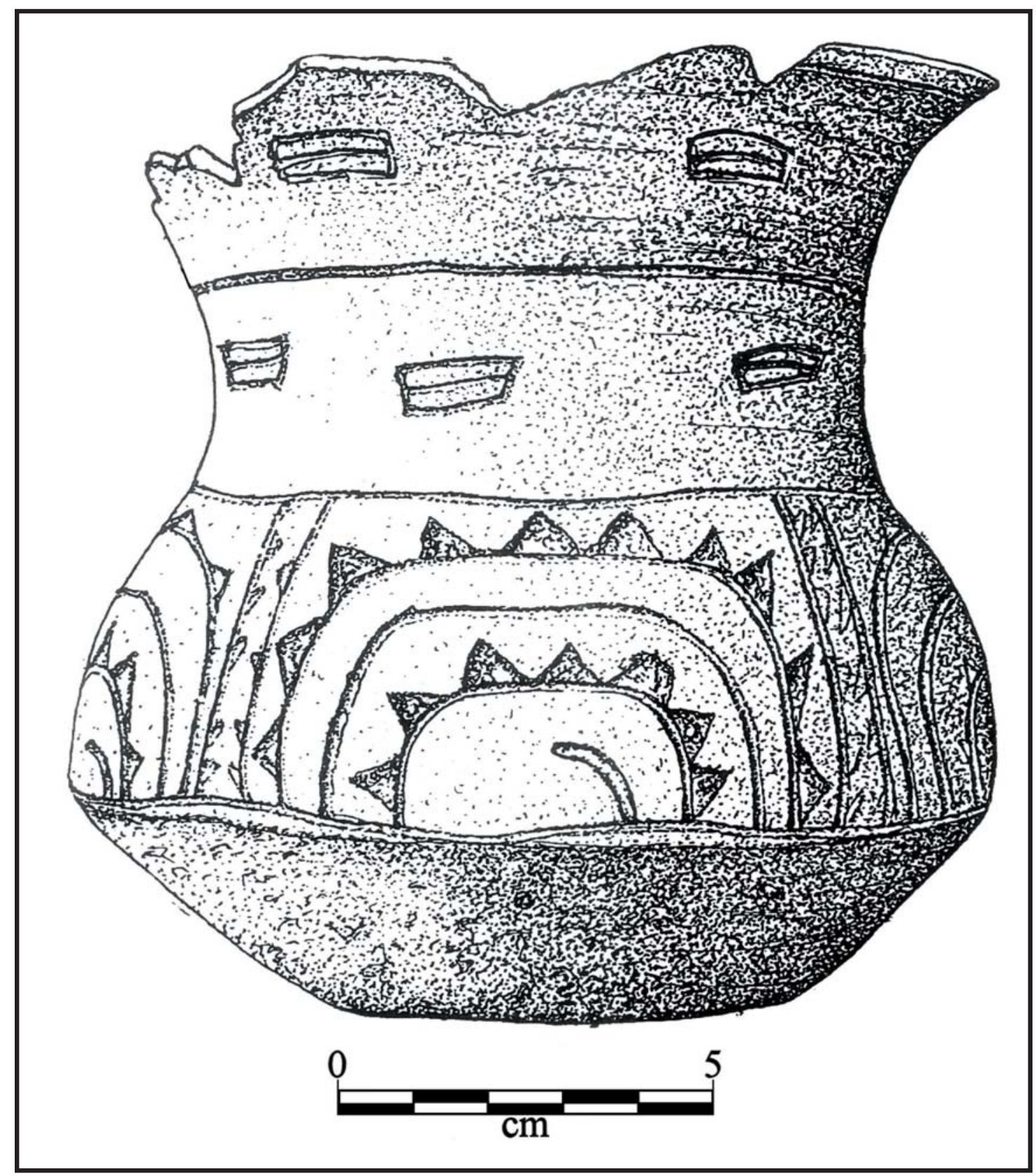

Figure 13. Burial 1 vessel 
Table 3. Ceramic Vessels from Burials 1-3.

\begin{tabular}{|c|c|c|c|c|c|}
\hline $\begin{array}{c}\text { Burial } \\
\text { No. }\end{array}$ & $\begin{array}{c}\text { Vessel } \\
\text { No. }\end{array}$ & Temper & $\begin{array}{c}\text { Orifice } \\
\text { Diameter }\end{array}$ & $\begin{array}{c}\text { Volume } \\
\text { (liters) } \\
(\mathrm{cm})\end{array}$ & Type \\
\hline 1 & 1 & shell-grog & 13.5 & 1.0 & $\begin{array}{l}\text { Avery } \\
\text { Engraved }\end{array}$ \\
\hline 2 & 1 & $\begin{array}{l}\text { grog-bone- } \\
\text { hematite }\end{array}$ & UID & 0.5 & $\begin{array}{l}\text { Wilder } \\
\text { Engraved }\end{array}$ \\
\hline 2 & 2 & grog-bone & 17.6 & 1.0 & $\begin{array}{l}\text { Ripley } \\
\text { Engraved }\end{array}$ \\
\hline 2 & 3 & $\begin{array}{l}\text { grog- } \\
\text { hematite }\end{array}$ & 9.5 & 0.47 & $\begin{array}{l}\text { possible } \\
\text { Moore Noded }\end{array}$ \\
\hline 2 & 4 & $\begin{array}{l}\text { grog-bone- } \\
\text { hematite }\end{array}$ & 10.2 & 0.65 & $\begin{array}{l}\text { Wilder } \\
\text { Engraved }\end{array}$ \\
\hline 2 & 5 & $\begin{array}{l}\text { grog-bone- } \\
\text { hematite }\end{array}$ & 13.5 & 0.33 & $\begin{array}{l}\text { Ripley } \\
\text { Engraved }\end{array}$ \\
\hline 3 & 1 & $\begin{array}{l}\text { grog-bone- } \\
\text { hematite }\end{array}$ & 13.5 & 0.75 & $\begin{array}{l}\text { Maydelle } \\
\text { Incised }\end{array}$ \\
\hline 3 & 2 & $\begin{array}{l}\text { grog-bone- } \\
\text { hematite }\end{array}$ & 5.0 & 0.8 & $\begin{array}{l}\text { Ripley } \\
\text { Engraved }\end{array}$ \\
\hline 3 & 3 & $\begin{array}{l}\text { grog-bone- } \\
\text { hematite }\end{array}$ & 11.4 & 0.38 & UID \\
\hline 3 & 4 & $\begin{array}{l}\text { grog-bone- } \\
\text { hematite }\end{array}$ & 11.9 & 0.5 & $\begin{array}{l}\text { Mockingbird } \\
\text { Punctated }\end{array}$ \\
\hline 3 & 5 & $\begin{array}{l}\text { grog-bone- } \\
\text { hematite }\end{array}$ & 10.7 & 0.2 & $\begin{array}{l}\text { Ripley } \\
\text { Engraved }\end{array}$ \\
\hline 3 & 6 & $\begin{array}{l}\text { grog-bone- } \\
\text { hematite }\end{array}$ & 9.3 & 0.4 & UID \\
\hline
\end{tabular}

UID= unidentified

The shell-tempered Avery Engraved vessel is from a Red River McCurtain phase Caddo group, as they are the only East Texas Caddo group that made shell-tempered pottery before ca. A.D. 1700 (Perttula et al. 2012). The other vessels from Burials 2 and 3, all grog-bone-hematite-tempered, are likely to have been manufactured locally by Titus phase Caddo potters. The vessels are small to medium-sized in volume and orifice diameter (see Table 3).

Burial 2 is that of an adolescent, based on the size of the burial pit (117 x $47 \mathrm{~cm}$ in length and width) and the funerary offerings; there were no preserved human remains. The grave is oriented northeast by southwest, and it is suspected that the individual was laid out in an extended supine position with their head 
at the southern end of the grave, near where a ceramic bottle had been placed. It is a common feature of Titus phase burials for a ceramic bottle to be placed in the immediate proximity of an individual's head. Funerary offerings with this individual include five ceramic vessels near what would have been the head and along both sides of the body. Four of the five vessels are engraved fine wares of the Wilder Engraved and Ripley Engraved types (Figure 14a-b, d-e), while the other is a distinctive noded carinated bowl. Lankford (2012) suggests such vessels are effigies of Datura (Jimson weed) seed pods, and a marker for the practice of Datura shamanism.

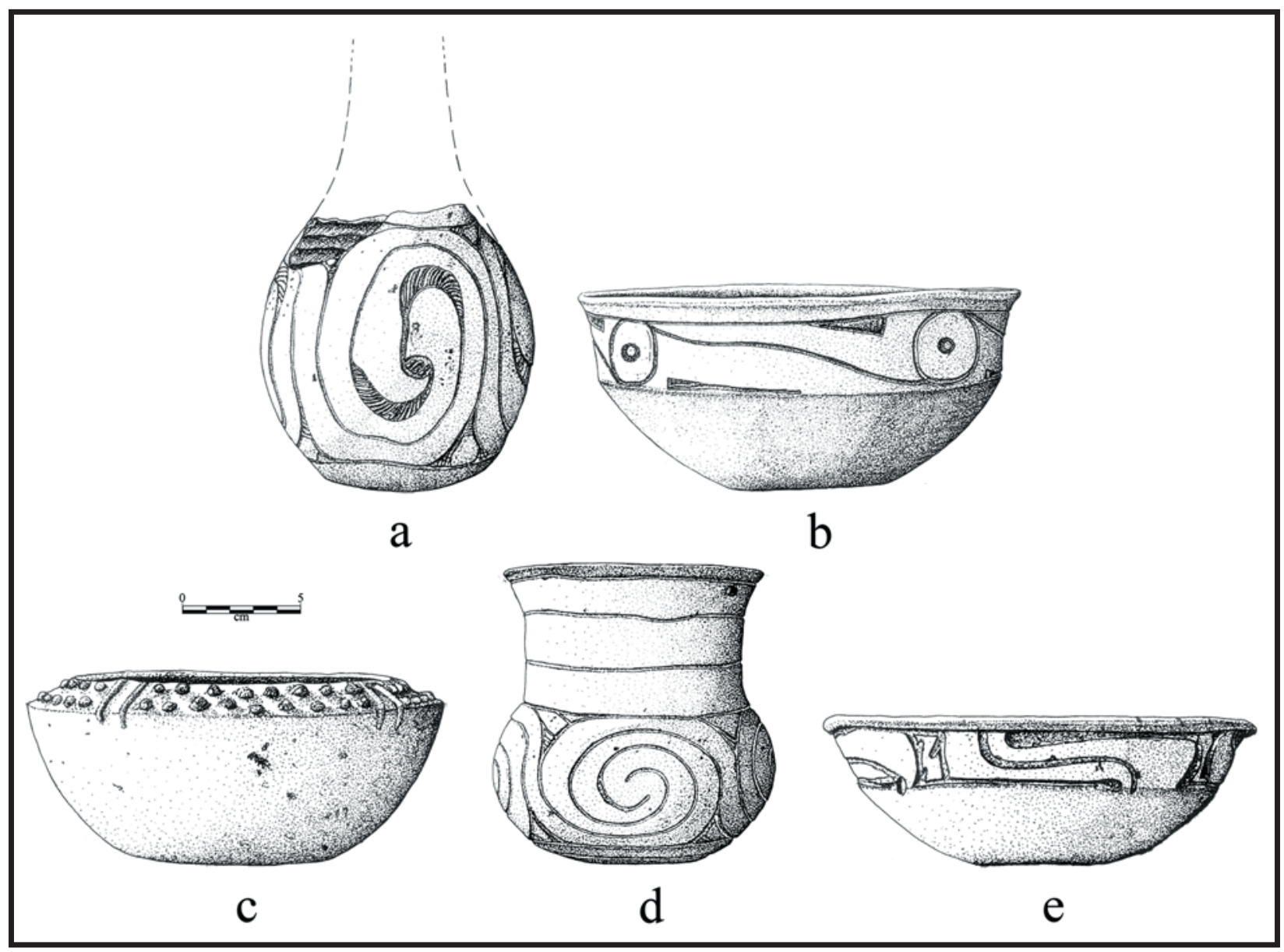

Figure 14. Burial 2 vessels: a, Wilder Engraved, var. Wilder bottle; b, Ripley Engraved, var. Galt carinated bowl; c, noded carinated bowl; d, Wilder Engraved, var. unspecified compound bowl; e, Ripley Engraved, var. Gandy carinated bowl.

Burial 3 may also have been that of an adolescent, as the burial pit is only $117 \times 78 \mathrm{~cm}$ in length and width; the pit is oriented northeast-southwest. As with Burial 2, there were no preserved human remains in the grave. Six ceramic vessels were placed in the grave as funerary offerings (see Table 3), clustered in the central and southern part of the grave (Perttula and Sherman 2009:Figure 6-21). Two of the vessels are plain (a jar and a cup or jar, Figure 15c, g), two are incised, punctated, and appliqued utility ware jars (Figure 15a, d), and the other two are fine wares. One of these is a large Ripley Engraved, var. Ripley bottle (Figure 15b) with circle and diamond elements and the other is a Ripley Engraved, var. Carpenter carinated bowl with a continuous scroll motif (Figure 15f). 


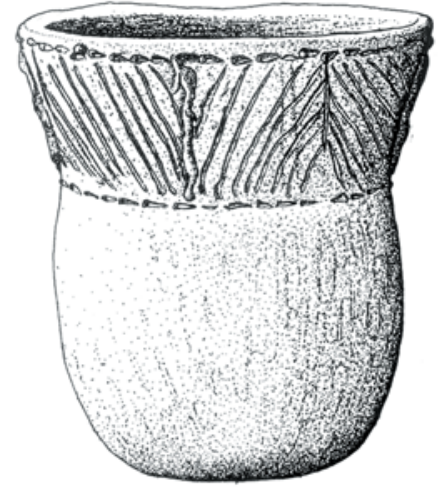

a

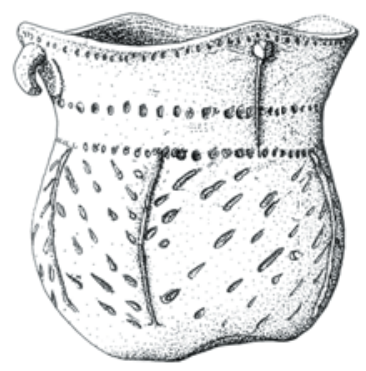

d

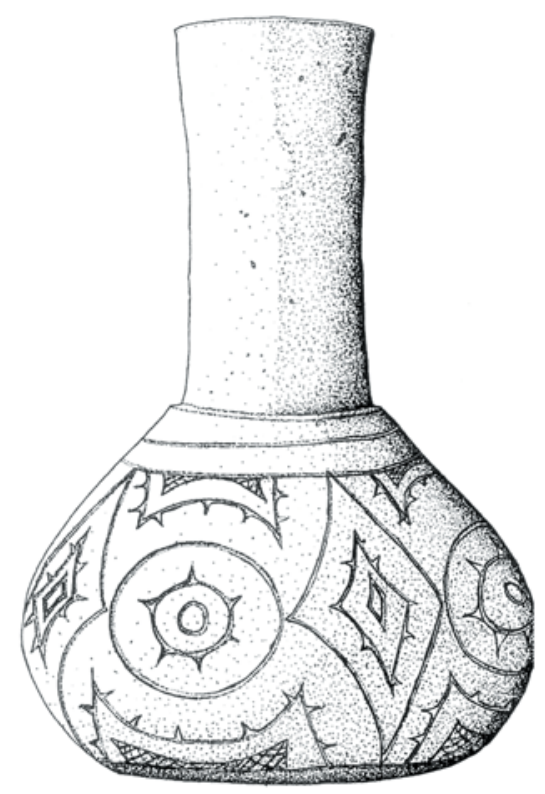

$\mathrm{b}$

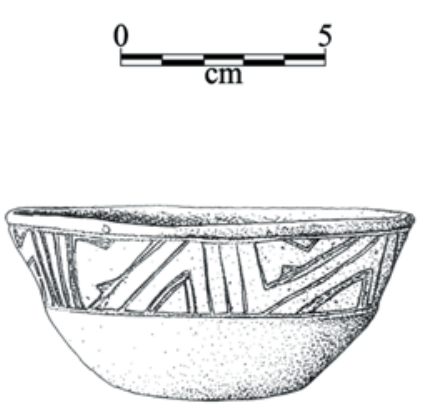

$\mathrm{f}$

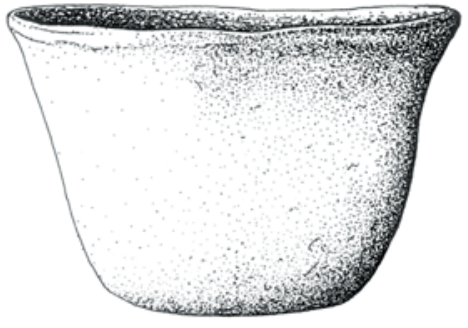

C

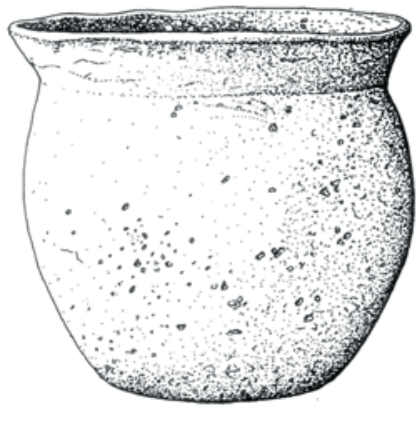

$\mathrm{g}$

Figure 15. Burial 3 vessels: a, Maydelle Incised jar; b, Ripley Engraved, var. Ripley bottle; c, plain miniature cup or jar; d, Mockingbird Punctated jar; e, Ripley Engraved, var. Carpenter carinated bowl; f, plain jar.

\section{Summary and Conclusions}

Archeological investigations at the Ear Spool site has uncovered important information about a prehistoric Caddo Indian settlement occupied during the Late Caddo period Titus phase. The occupation appears to have taken place at two different times, an earlier component (Component I) dating from ca. the mid- $15^{\text {th }}$ to early $16^{\text {th }}$ century A.D. and a later component (Component II) that may have lasted from ca. the mid- $16^{\text {th }}$ century to the early seventeenth century. Both occupations by Caddo peoples took place during lengthy periods of regional drought, especially that of the Component I occupation. Each component had a distinctive assemblage of decorated ceramic fine ware and utility ware vessels, and lithic assemblages from both components appear geared to the production and use of Maud arrow points. 
Four circular structures were identified at the Ear Spool site, two in the earlier component (Structure 1 and 3) and two in the later component (Structures 2 and 4). There was a broad, open area between the houses that may have been maintained as a small plaza or courtyard, as there are marker poles at its center, and there were clusters of pits along its margins. Three burials were present at the site, one child burial inside Structure 2 and adults in two widely separated areas; there apparently was no large family cemetery (i.e., 10-20 burials) at the Ear Spool site.

Component I is represented by Structures 1 and 3 and a handful of features outside of the structures in Area III. Both structures were erected in shallow circular pits, and Structure 1 had a long entranceway that faced southwest towards Structure 3. Prior to the beginning of the excavations at the Ear Spool site, no evidence was observed on the ground surface that indicated the presence of substructure mounds. Nevertheless, the structure pits for Structures 1 and 3 both contained multiple and apparently intentional cultural fill deposits as well as burned structural remains, possibly evidence of activity analogous to mound building or at least consecration of the place of the burned and buried structures. Such apparently symbolic treatment of Structures 1 and 3 suggests that these structures held a cultural significance beyond that of purely domestic concerns. The presence of a dense concentration of trash (including high densities of animal remains) in the fill for Structure 3 that was presumably deposited during the occupation of the slightly later Structure 1 suggests that these structures may have held dual roles, existing in both spiritual and secular worlds.

Whether Component II structures had symbolic import is uncertain. Neither of these structures showed evidence of mound-building activities or the burial of the houses with sediments, although Structure 2 was burned down, probably deliberately. However, both Component II structures were much larger than the Component I structures and had more-closely spaced posts, characteristics that may have held some architectural or cultural significance to the builders of the later structures at Ear Spool.

Based on ceramic and radiometric evidence, Structure 3 appears to represent the earliest structure built and used by the Caddo at the Ear Spool site, but Structure 1 followed shortly thereafter. Although these structures were architecturally similar, they differed profoundly in how they were abandoned. At the end of its use-life, Structure 1 was intentionally burned and carefully covered with sediments, almost certainly sediments that made a small mound that was eventually marked with a large pole that was embedded in the central portion of the Structure 1 hearth. In contrast, Structure 3 appears to have been dismantled and its pit subsequently used as a trash disposal area presumably for refuse from the inhabitants of Structure 1, and was eventually filled with sediment. The fact that few post features were preserved in Structure 3 when compared with Structure 1 suggests strongly that Structure 3 posts were not left to decay in place but were rather pulled, and possibly reused to construct Structure 1 . The conspicuous incomplete clay floor in Structure 3 compared with the virtually pristine floor in Structure 1 supports the notion that the Structure 3 floor was dismantled and possibly recycled during abandonment for use in Structure 1, or that the actions of pulling posts led to disturbance of the clay floor.

Component II is represented by Structures 2 and 4 and Burials 1-3, as well as a number of cooking and pit features located outside of the structures. The specific chronological relationship between the Component II structures remains uncertain. The results of the ceramic analysis suggest Structure 2 represents the final Titus phase occupation at Ear Spool, but this conclusion is probably affected by the small and almost certainly biased decorated sherd collection from Structure 4. The calibrated radiocarbon dates from the structures suggest the two structures are generally contemporaneous with each other, and with Feature 1, the large storage/trash pit situated just outside of Structure 4. Component II structures were larger than the earlier Component I structures, had more-closely spaced posts, and were built on the living surface rather than in a pit. 
That Structure 4 is different in some respects from the three other structures is evident, first, because it was not spatially aligned with any of the other structures at Ear Spool. Structure 4 was associated with an outdoor work area (with presumed drying racks, elevated work platforms or ramadas, and cooking features) located just outside of and to the north and east of the structure. These observations suggest that Structure 4 may not have been occupied as long as the other structures identified on-site and/or may not have been used in the same ways. Together, these observations hint that Structure 4 may actually represent the final occupational and constructional episode at the site.

The layout of the Ear Spool site indicates a level of planning that transcended individual occupational episodes. This can be seen in a near-complete lack of overprinting of features and archeological remains, which suggests that, generally speaking, different parts of the site were used during successive occupations. The fact that Structures 1 and 2, from two distinct occupations, are precisely aligned, also supports this idea. A line drawn from the central hearth of Structure 1 to the central hearth of Structure 2 evenly bisects the extended entranceway of Structure 1. It is unlikely that this is a fortuitous arrangement. It is a more reasonable conclusion that the individuals who built Structure 2 had prior knowledge of the location and layout of Structure 1. This inference is further supported by the fact that a post was placed in the center of the central hearth of Structure 1 following its abandonment and destruction, conceivably to mark the location. Three other marker poles, each one placed immediately next to the other, are found in the central open area between the four structures.

That evidence of long-term planning exists at the Ear Spool site is to be expected because the long-term spatial planning of settlements and features is apparent at other Caddo sites, particularly in the placement and arrangement of mortuary features and important structures probably used by the political and religious elite in restricted parts of sites, or in certain locations around plazas or courtyard areas. For example, the Tuck Carpenter site (41CP5) was a Titus phase cemetery that contained more than 70 graves in rows that did not overlap (Turner 1978, 1992), and the cemetery was used over a period at least as long as 50 years; other large Titus phase community cemeteries in the Big Cypress Creek basin evidenced the same level of planning (2012). The burial mound at the George C. Davis site (41CE19, Story 1998), although dating well before the Ear Spool occupation, showed multiple episodes of use, interment, and reuse by the Caddo, with very little intrusion of earlier interments into older ones. The placement and marking (with different colored clays) of each large burial pit was apparently long remembered by members of the local Caddo community.

Ancestral Caddo groups also had a tradition of burning, capping, and rebuilding important structures in and under mounds (see Trubitt 2009). Story (1998:34) refers to this as a continuing cycle of "destruction and renewal." Furthermore, Early (1988:161) has noted that this tradition can be:

used as an indicator of building function because it is so often associated with structures found on flat topped mounds, the context where most buildings have been studied. Because so few non-mound structures have been studied in detail in Arkansas, however, it is not clear that this treatment was designated for a class of buildings, a set of social circumstances, or particular places in the Caddoan [sic] community. Moreover, there is undoubtedly temporal and geographical variation in the kind, location and treatment of special purpose buildings among the various groups that inhabited the Caddo area.

Thus, the apparently intentional destruction by fire and capping of Structure 1 at the Ear Spool site is a treatment that is not uncommon for certain important Caddo structures (see Trubitt 2009). For example, most of the eight structures identified at the Belcher site (16CD13) were burned and buried (Webb 1959) in a mound, and although they appeared no different architecturally from domestic structures, their deliberate burial in a mound suggests they were used by the political and religious elite. 
The Titus phase house below Mound D at the Harroun site (41UR10, Jelks and Tunnell 1959) was strikingly similar to Structure 1 at the Ear Spool site. Both structures were semisubterranean circular structures with central hearths and extended entranceways. The other structures identified at Harroun, built on the surface, had sand banked around their perimeters. This practice is functionally or symbolically analogous to construction in a pit. At the Dalton site (41UR11, Davis and Gipson 1960), the structures had prepared clay floors. At some period of use-shown by the accumulation of midden deposits on the floors-these structures were deliberately set on fire by the Caddo, and burned structural debris (including much daub) collapsed onto the structure floors and filled up the pits. Then these burned structures were covered by sediments, as with Structure 1 at Ear Spool, to create a series of small earthen mounds.

It does appear to be the case that only a small number of Late Caddo period Titus phase mound sites are known in the region, perhaps as many as 12 different sites in the Big Cypress Creek basin, ranging from one to four mounds per site, with the largest mound complex (with platform mounds) at the Pine Tree Mound site (Fields and Gadus 2012; Perttula 2012: Figure 13-2). The Big Cypress Creek basin mounds are unlike the types of mound complexes typically constructed in the major river valleys in the southern Caddo area at this time. They were, as was the likely mound covering Structure 1 at Ear Spool, sub-structural mounds; no pyramidal platform or burial mounds are known for this time period. Sub-structural mounds are restricted to mounds that cap a burned circular structure that was constructed on the ground surface or in a small, shallow pit. In at least two instances, Big Cypress Creek mounds contained sequent structures, but the "structures originated at higher levels in the mound[s] due to occupational accumulations of soil and ash, and not the result of any deliberate capping" (Thurmond 1990:168). At the Camp Joy Mound (41UR144), the $2.3 \mathrm{~m}$ high mound apparently had two tiers or platforms, with the latest platform having a burned structure (marked by a $7 \mathrm{~cm}$ thick charcoal lens) dated to cal A.D. 1495-1605 (see Perttula and Nelson 2001).

The structures that were capped by the mound, or built at higher levels in the mound itself (as at Harroun), were circular, with extended entranceways facing west (or southwest, in the case of Structure 1 at Ear Spool), and with central hearths. These distinctive extended entranceway circular structures (Perttula 2009) — found primarily in the Red and Big Cypress basins after ca. A.D. 1400 (Figure 16)—were partially dismantled and burned, then capped with sediments. Again at the Harroun site, the structures were built inside large circular pits, and there were obvious soil berms around the enclosing pit and the structure. A standing structures with berms around would look like the structure was literally buried (or partially buried) in the mound itself (cf. Schambach 1996). At the Dalton site, two temporally sequent circular structures (with claylined floors) of slightly different sizes were both built and used within the same shallow pit; when the second one was burned and destroyed, it and the surrounding pit were buried by a sandy mound fill to a depth of $80 \mathrm{~cm}$ (Davis and Gipson 1960:17-19; Thurmond 1990:210). At the Whelan site, one of the mounds had four temporally sequent structures that ranged from 5.2-6.4 $\mathrm{m}$ in diameter (Thurmond 1990:168). 


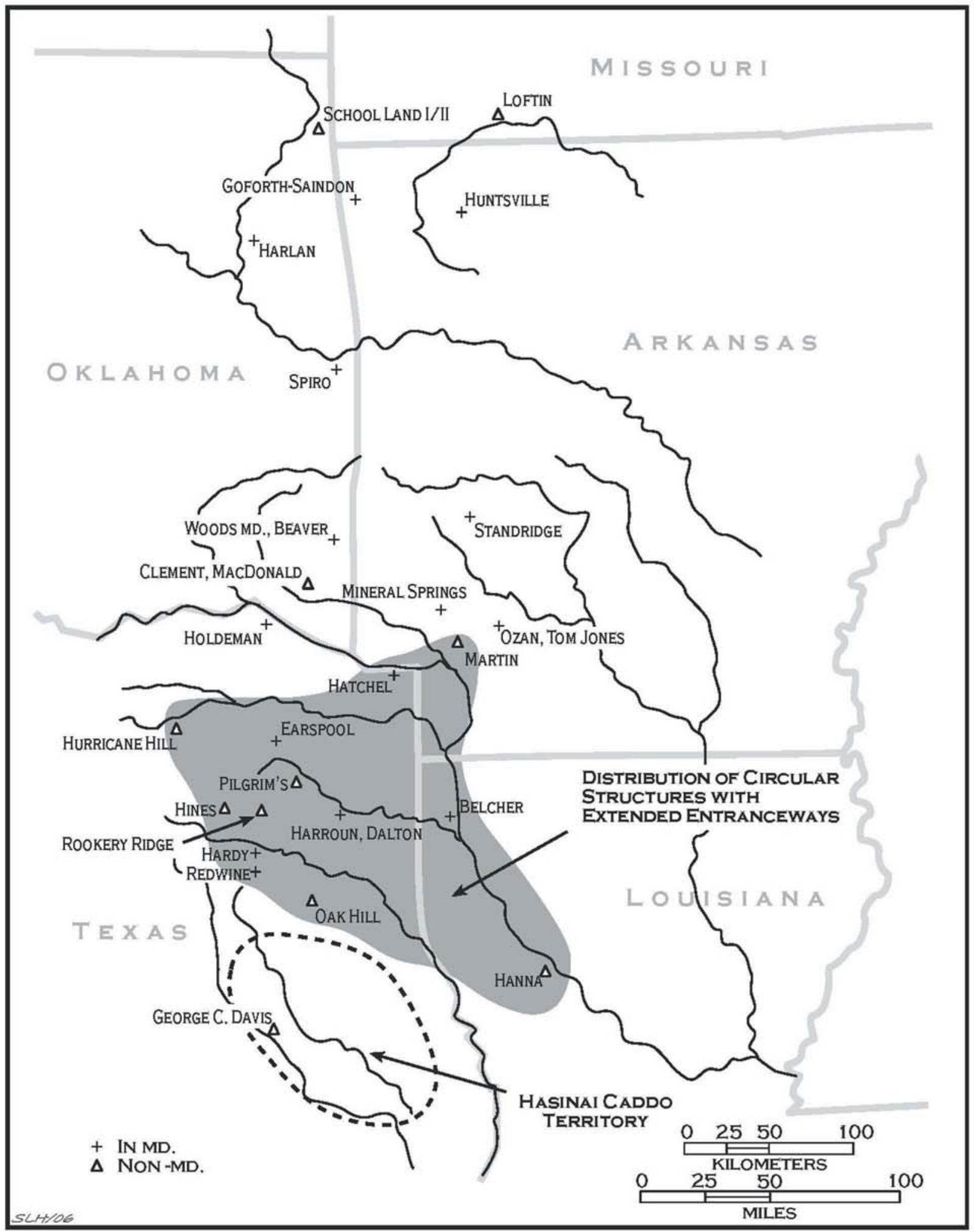

Figure 16. Distribution of circular extended entranceway structures in the Caddo area, including the Ear Spool site. 
It is not clear what triggered the dismantling and burning of the structures, or their capping with mound sediments at the Titus phase community centers, but given the generally close association between the mound places and the community cemeteries (many of which held the burials of members of the social elite, including lineage heads), it seems plausible that the house destruction and mound building episodes occurred after the death and burial of a leader or a member of the social elite. However, these elite individuals were buried with their peers and kin-affiliated relations in the community cemetery, not in the mound itself, and thus in essence the mound-building rituals of the Titus phase Caddo consisted of "public building-oriented ceremonialism" (Schambach 1996:41), such that the mounds "contain the remains of important buildings rather than important people." Such appears to be the case at the Ear Spool site.

This dichotomy between mound and habitation associations on Titus phase mounds, with the main multi-mound centers at the Harroun and Whelan sites having little if no associated habitation debris, while most of the other mounds did, leads to the suspicion that there were fundamental and measurable differences in the complexity (if not wealth and prestige) of the different political communities in the Big Cypress Creek basin. For most of the communities, including the community of which Ear Spool was a part, the ritual, power, and authority of the elite leaders had not been divorced from the populations living in the communities, especially those living in and near the largest villages. This intimate relationship-as seen by the placement of mounds across the landscape-between the community and its leaders was not duplicated in Titus phase Caddo communities living along the lower Big Cypress Creek basin and near the eastern margins of the settlement distribution of the Titus phase. Here, the community mound centers were basically kept separate from domestic affairs and were focused more exclusively on ritual activities and the control of ritual knowledge. Those leaders that lived at the Harroun and Whelan sites may have gained their prestige and authority through their control of community-wide ritual affairs.

Recent excavations at the Ear Spool, Pilgrim's Pride (41CP304), and Rookery Ridge (41UR133) sites have provided solid archeological evidence of how Titus phase domestic settlements in the Big Cypress and Sulphur River basins were organized and laid out spatially, as do the very extensive excavations in village areas at the Pine Tree Mound site (41HS15) in the Sabine River basin (Perttula 2005; Parsons 1998, 2011; Fields and Gadus 2012). The settlements and village areas at each site appear to have been composed of one to several family units with house midden/daub concentrations and trash midden deposits; many activities occurred outside the house areas, resulting in trash-filled pits, hearths, and posts in these areas. At Pilgrim's Pride, there were several circular structures in the habitation area, set away from a single earthen mound at one end of the settlement, and with a large cemetery at the other end. Numerous pits were present outside of the structures, indicating, like at Ear Spool, that many activities (i.e., cooking, food processing, tool manufacture, etc.) took place in open outdoor work areas. The Rookery Ridge site excavations exposed two circular structures and extensive midden deposits. The middens were about $15 \mathrm{~m}$ south of the one structure with an extended entranceway; the entranceway faced to the north, suggesting that other habitation features besides those excavated by Parsons $(1998,2011)$ were present on the northern part of the alluvial landform along Kelsey Creek. Child and adult burials were present either inside a structure or immediately outside, along the structure walls, but again as at Ear Spool, there was no larger family cemetery at the site. There were family cemeteries at both Pilgrim's Pride and Pine Tree Mound.

Animal faunal and mussel shell subsistence remains were recovered in far greater numbers from Structure 3 than any other context across the site (Perttula and Sherman 2009:Table 15-2, pointing to its trash disposal use following its burning and abandonment. Although the volume of faunal materials recovered from Component I and II contexts varied widely across the site, the relative proportion of species identified did not 
significantly differ. This suggests that during both components similar ranges of subsistence resources were utilized (or at least returned to the site for processing), primarily focused on deer and an assortment of smaller mammals. It is likely that small herds of bison roamed the tall-grass prairie in Late Holocene times, although it would have been a considerable trek to the tall-grass prairies in the upper Sulphur River basin for Titus phase hunters who did not yet have any horses. The high density of arrow points (primarily Maud) and scraping tools, as well as signs of intensive arrow point manufacture (in Structure 2 and outdoor work area 3, both in Component II), at the Ear Spool site ( and Sherman 2009:Table 12-1), however, suggest that this particular Caddo population was intensively exploiting large game animals, including deer and bison. The meat from any bison kills was likely processed at the kill site, with bones discarded there, to lighten the transport load on the trek back from the tall-grass prairie to the site.

Maize was cultivated during both Component I and II occupations, and squash and maygrass were recovered from a Component I context (Perttula and Sherman 2009:346-348). The ubiquity of maize (24\%) is somewhat lower than has been documented at other Titus phase sites, all in the Big Cypress Creek or Sabine River basins, suggesting that the Ear Spool Caddo living in the Post Oak Savanna relied less on cultivated plants in their diet than did their neighbors to the south who lived in the Pineywoods. Nevertheless, the Late Caddo agricultural lifeway probably was flourishing in parts of northeastern Texas (likely those areas with the highest agricultural potential) at least in part due to quite adequate growing season rainfall from the late 14th century through the first quarter of the 15th century, and in the late $15^{\text {th }}$ to early $16^{\text {th }}$ century (A.D. 1477-1524), and from A.D. 1539-1572. However, there were extensive periods of drought between A.D. 1430-1476, A.D. 1525-1538, and A.D. 1573-1602 (Perttula 2013:Table 3.2). Both Caddo occupations at the Ear Spool site lasted apparently through these droughts. During droughty periods that sometimes lasted for several years, the effects of the droughts must have been localized, because there is a general continuity of Titus phase settlement across many parts of the Sabine and Big Cypress Creek basins that suggests crops were successfully grown and harvested even in these droughty periods. The long-term storage of plant foods and seed stock-perhaps in above-ground granaries as well as below-ground storage pits-also would have helped to offset losses from poor or failed harvests.

Hardwood mast, especially hickory and acorn nuts, were conversely an important aspect of the subsistence regime, and these tree resources were no doubt spatially abundant in the surrounding forest. There was an extensive ground stone tool assemblage that was employed to pound and grind plant these plant remains, probably primarily for the production of corn hominy and hickory nut oils.

A number of arrow points ( $n=53)$, arrow point preforms ( $n=20)$, bifacial and unifacial tools $(n=144)$, cores, and lithic debris were recovered from both components at Ear Spool, indicating that the production of hunting, scraping, and cutting tools was important to the Caddo residents, particularly during Component II times. It is possible that a stone tool knapper lived in Structure 2, based on the density of recovered arrow points there (Perttula and Sherman 2009:Table 12-4). The abundance of stone tools and the debris from stone tool manufacture suggests that the hunting of large game-perhaps focused on animal resources that ranged in the nearby tall grass prairie, including bison-was a particular focus of the adult men and women living at Ear Spool.

The habitation areas at Ear Spool are small, covering less than 1 acre. They are closely associated with the structures themselves as well as with outdoor work areas. The Ear Spool burials may be part of a small family cemetery associated with the use of Structures 2 and 4 during Component II times. The family cemeteries are generally found in the immediate proximity to a farmstead or hamlet, and they contain few interments by 
comparison to the much larger community cemeteries. Grave good associations and burial treatment of Caddo peoples in Titus phase family cemeteries do not show much evidence among these individuals for differential status or social rank. Artifact associations in family cemeteries differed only by age and sex: Adolescents were buried with more offerings than children or infants, and with fewer offerings than adults; at Ear Spool, the one child burial had only a single vessel placed with it, while the two adolescent burials had 5 or 6 vessels placed with them as funerary offerings.

\section{Acknowledgements}

Lance Trask prepared all the figures in this article, except for Figure 12, which was provided by Zac Selden.

\section{References Cited}

Carter, C. E.

1995 Caddo Indians: Where We Came From. University of Oklahoma Press, Norman.

Chesson, M. S.

2001 Social Memory, Identity, and Death: An Introduction. In Social Memory, Identity, and Death: Anthropological Perspectives on Mortuary Rituals, edited by M. S. Chesson, pp. 1-10. Archeological Papers No. 10. American Anthropological Association, Washington, D.C.

Davis, E. M. and J. Gipson

1960 The Dalton Site: A Late Caddoan Mound Site in the Ferrell's Bridge Reservoir Area, Northeastern Texas. Division of Research in Anthropology, The University of Texas at Austin.

Early, A. M.

1988 Standridge: Caddoan Settlement in a Mountain Environment. Research Series No. 29. Arkansas Archeological Survey, Fayetteville.

Fields, R. C. and E. F. Gadus (editors)

2012 Archeology of the Nadaco Caddo: The View from the Pine Tree Mound Site (41HS15), Harrison County, Texas. 2 Vols. Reports of Investigations No. 164. Prewitt and Associates, Inc., Austin.

Galan, V.

1998 Excavations at 41TT653, the Ear Spool Site. CRM News \& Views 10(2):21-25. Archeology Division, Texas Historical Commission, Austin.

Jelks, E. B., and C. D. Tunnell

1959 The Harroun Site, A Fulton Aspect Component of the Caddoan Area, Upshur County, Texas. Archaeology Series No. 2. Department of Anthropology, The University of Texas at Austin.

Lankford, G. E.

2012 Weeding out the Noded. The Arkansas Archeologist 50:50-68. 
Parsons, M.

1998 41UR133: A Late Caddo Hamlet at Lake Gilmer. Cultural Resource Management News \& Views 10(1):16-19. Division of Antiquities Protection, Texas Historical Commission, Austin.

2011 Mitigation Phase Archeological Investigations at Lake Gilmer, Upshur County, Texas. MS on file, Archeology Division, Texas Historical Commission, Austin.

Pauketat, T. R. and S. M. Alt

2005 Agency in a Postmold? Physicality and the Archaeology of Culture-Making. Journal of Archaeological Method and Theory 12(3):213-236.

Perttula, T. K.

2005 (Editor) Archeological Investigations at the Pilgrim's Pride Site (41CP304), a Titus Phase Community in the Big Cypress Creek Basin, Camp County, Texas. 2 Vols. Report of Investigations No. 30. Archeological \& Environmental Consultants, LLC, Austin.

2009 Extended Entranceway Structures in the Caddo Archaeological Area. Southeastern Archaeology 28(1):27-42.

2012 The Character of Fifteenth- to Seventeenth-Century Caddo Communities in the Big Cypress Creek Basin of Northeast Texas. In The Archaeology of the Caddo, edited by T. K. Perttula and C. P. Walker, pp. 363-410. University of Nebraska Press, Lincoln.

2013 Risky Business: Caddo Farmers living at the Edge of the Eastern Woodlands. In Comparative Archaeology and Paleoclimatolgy: Socio-cultural responses to a changing world, edited by M. 0. Baldia, T. K. Perttula, and D. S. Frink, pp. 21-34. BAR International Series 2456. Archaeopress, Oxford, England.

Perttula, T. K. and B. Nelson

2001 Archeological Investigations at the Camp Joy Mound (41UR144): A Titus Phase Earthen Mound at Lake $O^{\prime}$ the Pines, Upshur County, Texas. Report of Investigations No. 44. Archeological and Environmental Consultants and Friends of Northeast Texas Archaeology, Austin and Pittsburg.

Perttula, T. K. and D. L. Sherman

2009 Data Recovery Investigations at the Ear Spool Site (41TT653), Titus County, Texas. Document No. 070205. PBS\&J, Austin.

Perttula, T. K., M. B. Trubitt, and J. S. Girard

2012 The Use of Shell-Tempered Pottery in the Caddo Area of the Southeastern United States. Southeastern Archaeology 30(2):242-267.

Schambach, F. F.

1996 Mounds, Embankments, and Ceremonialism in the Trans-Mississippi South. In Mounds, Embankments, and Ceremonialism in the Midsouth, edited by R. C. Mainfort and R. Walling, pp. 3643. Research Series No. 46. Arkansas Archeological Survey, Fayetteville.

Story, D. A.

1998 The George C. Davis Site: Glimpses into Early Caddoan Symbolism and Ideology. In The Native History of the Caddo: Their Place in Southeastern Archeology and Ethnohistory, edited by T. K. Perttula and J. E. Bruseth, pp. 9-43. Studies in Archeology 30. Texas Archeological Research Laboratory The University of Texas at Austin. 
Thurmond, J. P.

1990 Archeology of the Cypress Creek Drainage Basin, Northeastern Texas and Northwestern Louisiana. Studies in Archeology 5. Texas Archeological Research Laboratory, The University of Texas at Austin.

Trubitt, M. B.

2009 Burning and Burying Buildings: Exploring Variation in Caddo Architecture in Southwest Arkansas. Southeastern Archaeology 28(2):233-247.

Turner, R. L.

1978 The Tuck Carpenter Site and Its Relations to Other Sites within the Titus Focus. Bulletin of the Texas Archeological Society 49:1-110.

1992 Prehistoric Mortuary Remains at the Tuck Carpenter Site, Camp County, Texas. Studies in Archeology No. 10. Texas Archeological Research Laboratory, The University of Texas at Austin.

Webb, C. H.

1959 The Belcher Mound, a Stratified Caddoan Site in Caddo Parish, Louisiana. Memoirs No. 16. Society for American Archaeology, Salt Lake City. 